\title{
Linking marine phytoplankton emissions, meteorological processes, and downwind particle properties with FLEXPART
}

\author{
Kevin J. Sanchez ${ }^{1,2}$, Bo Zhang ${ }^{3}$, Hongyu Liu ${ }^{3}$, Georges Saliba ${ }^{4}$, Chia-Li Chen ${ }^{4}$, Savannah L. Lewis ${ }^{4}$, \\ Lynn M. Russell ${ }^{4}$, Michael A. Shook ${ }^{2}$, Ewan C. Crosbie ${ }^{2,5}$, Luke D. Ziemba ${ }^{2}$, Matthew D. Brown ${ }^{2,5}$, \\ Taylor J. Shingler ${ }^{2}$, Claire E. Robinson ${ }^{2,5}$, Elizabeth B. Wiggins ${ }^{1,2}$, Kenneth L. Thornhill ${ }^{2,5}$, Edward L. Winstead ${ }^{2,5}$, \\ Carolyn Jordan $^{2,3}$, Patricia K. Quinn ${ }^{6}$, Timothy S. Bates ${ }^{6,7}$, Jack Porter ${ }^{9}$, Thomas G. Bell ${ }^{8,9}$, Eric S. Saltzman ${ }^{9}$, \\ Michael J. Behrenfeld ${ }^{10}$, and Richard H. Moore ${ }^{2}$
}

${ }^{1}$ NASA Postdoctoral Program, Universities Space Research Association, Columbia, MD, USA

${ }^{2}$ NASA Langley Research Center, Hampton, VA, USA

${ }^{3}$ National Institute of Aerospace, Hampton, VA, USA

${ }^{4}$ Scripps Institution of Oceanography, University of California San Diego, La Jolla, CA, USA

${ }^{5}$ Science Systems and Applications, Inc., Hampton, VA, USA

${ }^{6}$ Pacific Marine Environmental Laboratory, NOAA, Seattle, WA, USA

${ }^{7}$ Joint Institute for the Study of the Atmosphere and Ocean (JISAO), University of Washington, Seattle, WA, USA

${ }^{8}$ Plymouth Marine Laboratory, Prospect Place, Plymouth, United Kingdom

${ }^{9}$ The Department of Earth System Science, University of California, Irvine, CA, USA

${ }^{10}$ Department of Botany and Plant Pathology, Oregon State University, Corvallis, OR, USA

Correspondence: Kevin J. Sanchez (kevin.j.sanchez@nasa.gov) and Richard H. Moore (richard.h.moore@nasa.gov)

Received: 11 July 2020 - Discussion started: 17 September 2020

Revised: 13 November 2020 - Accepted: 15 November 2020 - Published: 20 January 2021

\begin{abstract}
Marine biogenic particle contributions to atmospheric aerosol concentrations are not well understood though they are important for determining cloud optical and cloud-nucleating properties. Here we examine the relationship between marine aerosol measurements (with satellites and model fields of ocean biology) and meteorological variables during the North Atlantic Aerosols and Marine Ecosystems Study (NAAMES). NAAMES consisted of four field campaigns between November 2015 and April 2018 that aligned with the four major phases of the annual phytoplankton bloom cycle. The FLEXible PARTicle (FLEXPART) Lagrangian particle dispersion model is used to spatiotemporally connect these variables to ship-based aerosol and dimethyl sulfide (DMS) observations. We find that correlations between some aerosol measurements with satellitemeasured and modeled variables increase with increasing trajectory length, indicating that biological and meteorological processes over the air mass history are influential for measured particle properties and that using only spatially coincident data would miss correlative connections that are
\end{abstract}

lagged in time. In particular, the marine non-refractory organic aerosol mass correlates with modeled marine net primary production when weighted by $5 \mathrm{~d}$ air mass trajectory residence time $(r=0.62)$. This result indicates that nonrefractory organic aerosol mass is influenced by biogenic volatile organic compound (VOC) emissions that are typically produced through bacterial degradation of dissolved organic matter, zooplankton grazing on marine phytoplankton, and as a by-product of photosynthesis by phytoplankton stocks during advection into the region. This is further supported by the correlation of non-refractory organic mass with $2 \mathrm{~d}$ residence-time-weighted chlorophyll $a(r=0.39)$, a proxy for phytoplankton abundance, and $5 \mathrm{~d}$ residencetime-weighted downward shortwave forcing $(r=0.58)$, a requirement for photosynthesis. In contrast, DMS (formed through biological processes in the seawater) and primary marine aerosol (PMA) concentrations showed better correlations with explanatory biological and meteorological variables weighted with shorter air mass residence times, which reflects their localized origin as primary emissions. Aerosol 
submicron number and mass negatively correlate with sea surface wind speed. The negative correlation is attributed to enhanced PMA concentrations under higher wind speed conditions. We hypothesized that the elevated total particle surface area associated with high PMA concentrations leads to enhanced rates of condensation of VOC oxidation products onto PMA. Given the high deposition velocity of PMA relative to submicron aerosol, PMA can limit the accumulation of secondary aerosol mass. This study provides observational evidence for connections between marine aerosols and underlying ocean biology through complex secondary formation processes, emphasizing the need to consider air mass history in future analyses.

\section{Introduction}

Marine environments are sensitive to aerosol particle loading because particles can act as cloud condensation nuclei (CCN) on which cloud droplets form. The number concentration of cloud droplets can influence cloud optical properties and therefore affect the impact of clouds on climate (Leahy et al., 2012; Platnick and Twomey, 1994; Turner et al., 2007; Warren et al., 1988). Measurements over the ocean are scarce and have historically been concentrated over relatively few areas for short time periods aligning with episodic intensive ship or aircraft campaigns. Satellite measurements are crucial to filling this void in marine boundary layer (MBL) measurements, but satellite optical measurements of particles are disproportionally weighted by the largest optically active $(>300 \mathrm{~nm}$ diameter) particles (Hasekamp et al., 2019). An unresolved challenge is to relate these remote sensing measurements to the particle number, size distribution, and chemical composition that are known to drive variability in cloud properties. Since ocean-emitted volatile compounds and particles can control the number, size, and composition of marine aerosols (Brooks and Thornton, 2018), here we use satellite measurements of ocean biomass as a proxy for marine particle properties.

In the absence of advected continental or anthropogenic pollution, the main source of MBL particles is sea salt from primary marine aerosol (PMA), dissolved organic matter, and marine biogenic volatile organic compound (VOC) emissions that can oxidize and condense to form secondary aerosol mass (Bates et al., 1998a; Covert et al., 1992; Frossard et al., 2014b; Murphy et al., 1998; Quinn et al., 2000, 2014; Rinaldi et al., 2010; Sievering et al., 1992, 1999; Warren and Seinfeld, 1985). Clear seasonal trends have been identified between ocean chlorophyll $a$, a frequently used proxy for marine biomass, and marine biogenic particle production (O'Dowd et al., 1997; Ovadnevaite et al., 2014; Van Pinxteren et al., 2017; Saliba et al., 2020; Shaw, 1983). This observed seasonal trend results from the marine phytoplankton cycle, which is driven by ocean mixed layer deepening in the winter months, increasing nutrients at the surface and decoupling phytoplankton from predators, followed by increased sunlight in the spring, enhancing photosynthetic primary productivity; together they produce the annually occurring North Atlantic phytoplankton bloom (Behrenfeld, 2010; Behrenfeld and Boss, 2018; Boss and Behrenfeld, 2010). The bloom ends when phytoplankton division rates stop increasing (due to depletion of nutrients or an annual maximum in mixed layer light intensity) and are matched by loss rates (Behrenfeld and Boss, 2018). When bloom termination is associated with nutrient exhaustion, mixed later depths may continue to shoal into summer (i.e., mixed layer light levels are still increasing), but phytoplankton biomass may decrease due to slowing division rates and excessive grazing (Behrenfeld and Boss, 2018).

Analysis of phytoplankton taxonomy and its seasonal variability in the NAAMES region is presented by Bolaños et al. (2020). Bolaños et al. (2020) show that cyanobacteria dominated subpolar waters during the winter and were a significant fraction in the subtropics, with taxa varying by latitude. In addition, prasinophyta accounted for a significant contribution of subtropical species, with stramenopiles representing less than $30 \%$ of subtropical communities. Spring communities had significantly more diverse communities and significantly less cyanobacteria $(<10 \%)$ relative to the winter, with the exception of one station. Prasinophyta dominated the spring phytoplankton composition, though taxonomic compositions differed from the winter period and between the subpolar and subtropical regions. Typically, diatoms are assumed to be the dominant phytoplankton species in blooms. However, diatoms only represent $10 \%-40 \%$ of phytoplankton biomass in the spring bloom surveyed during NAAMES. The phytoplankton functional groups present influence the overall isoprene production rate and therefore the marine atmospheric aerosol and VOC concentrations. Booge et al. (2016) compiled chlorophyll-normalized isoprene production rates from the literature to identify differences between phytoplankton species. The chlorophyllnormalized isoprene production rates varied from 4.56-27.6, 1.4-32.16, and 1.12-28.48 ( $\mu \mathrm{mol}$ (g chlorophyll $a)^{-1} \mathrm{~d}^{-1}$ ) for cyanobacteria, prasinophyta, and diatoms, respectively, indicating that emissions for isoprene vary significantly with taxonomy. To further complicate the emission strength of VOCs, emissions can vary by production pathways, such as photosynthetic by-products, bacterial degradation of dissolved organic matter, and zooplankton grazing on marine phytoplankton (Gantt et al., 2009; Shaw et al., 2003; Sinha et al., 2007). One of the most studied biogenically produced marine aerosol components is non-sea-salt sulfate $\left(\mathrm{nssSO}_{4}^{2-}\right)$ because of its role as a proposed link to a biological thermostat on clouds (Charlson et al., 1987; Shaw, 1983), a notion that has been called into question (Quinn and Bates, 2011). Marine $\mathrm{nsSSO}_{4}^{2-}$ is formed from the oxidation products of dimethyl sulfide (DMS), a VOC derived from marine ecosystem processes (Yoch, 2002). The phytoplankton cycle 
leads to a seasonal variation in DMS-derived sulfate aerosol mass, with higher sulfate concentrations during bloom periods (Bates et al., 1998a; Bell et al., 2021; Frossard et al., 2014b; Park et al., 2017; Quinn et al., 2019; Sanchez et al., 2018). DMS-derived sulfuric acid can either increase the size of pre-existing MBL particles by adding to the aerosol sulfate mass through condensation or nucleate new particles in regions where the existing particle surface area is deficient. While a seasonal relationship between DMS and marine $\mathrm{nssSO}_{4}^{2-}$ mass exists, a direct temporal link is often not clear due to the range of chemical pathways affecting the yields of secondary aerosol formation and influence of entrainment on the formation of new particles (Andreae and Crutzen, 1997; Ayers et al., 1997; Bates et al., 1998a; Chen and Jang, 2012; Clarke et al., 1999, 2013; O'Connor et al., 2008; Reus et al., 2000; Sanchez et al., 2018; Veres et al., 2020). The formation rate of the DMS oxidation products methane sulfonic acid (MSA), sulfuric acid, and hydroperoxymethyl thioformate is a function of temperature and availability of atmospheric oxidants (Seinfeld and Pandis, 2006; Veres et al., 2020). Mixing of DMS across the MBL inversion, typically driven by convective or buoyancy-driven transport, can lead to subsequent entrainment of newly formed particles back into the MBL. New particle formation is thought to be favored in the free troposphere due to the colder temperatures and low pre-existing particle surface area (Clarke, 1993; Clarke et al., 2013; Raes et al., 1997; Russell et al., 1998; Sanchez et al., 2018; Seinfeld and Pandis, 2006; Thornton et al., 1997; Yue and Deepak, 1982). Furthermore, sulfate mass can rapidly form onto existing particles through cloud processing, which enhances rates of sulfur dioxide (a DMS oxidation product and precursor to sulfuric acid) condensation onto cloud droplets due to the enhanced surface area provided by the addition of water. Aqueous-phase oxidation of sulfur dioxide results in the formation of low-volatility sulfuric acid, which remains in the particle phase when the cloud dissipates. This shifts some particles from the Aitken to accumulation mode and gives rise to the distinctive "Hoppel minimum" (a minimum in the particle size distribution concentration between the two modes), commonly observed in cloud-processed marine aerosol size distributions (Hoppel et al., 1986).

Secondary organic aerosol mass is formed through the oxidation of biogenic VOCs such as isoprene and monoterpenes (Altieri et al., 2016; Hallquist et al., 2009). At Cape Grim, chlorophyll $a$, an indicator for marine phytoplankton biomass, is shown to strongly correlate with organic mass ( $r=0.85$ ) on a seasonal timescale (Cui et al., 2019). While isoprene and monoterpenes are known precursors for secondary organic particle mass, models indicate that previously observed particle yields and estimated air-sea fluxes of isoprene $\left(2 \%, 13-38 \mu \mathrm{g} \mathrm{m}^{-2} \mathrm{~d}^{-1}\right)$ and monoterpenes $(\sim 32 \%$, $0.27-0.78 \mu \mathrm{g} \mathrm{m}^{-2} \mathrm{~d}^{-1}$ ) (Hu et al., 2013; Lee et al., 2006) are too low to account for the observed MBL organic mass, suggesting that there may be large undiscovered sources (Arnold et al., 2009; Myriokefalitakis et al., 2010). One proposed pos- sible source is secondary organic precursors derived from photosensitized reactions of dissolved organic matter present in the sea surface microlayer (Cui et al., 2019). In addition, organic aerosol mass has been shown to correlate with black carbon (BC) and other continental tracers indicating that a large portion of the mass is not of marine origin (Saliba et al., 2020; Shank et al., 2012). Despite the presence of continental organic mass from long-range transport and primary OM, marine biogenically emitted VOCs are estimated to account for more than $60 \%$ of organic compounds over remote oceans (Brüggemann et al., 2018). Similarly, dual carbon isotope analysis of marine aerosol indicates that $80 \%$ of all primary and secondary organic matter is from biogenic origin during non-polluted conditions (Ceburnis et al., 2011). For the North Atlantic Aerosols and Marine Ecosystems Study (NAAMES) campaigns, Saliba et al. (2020) noted that measured submicron non-refractory nitrate mass (a product of secondary processes) strongly correlated with the non-refractory organic mass, suggesting that much of the non-refractory organic mass is secondary. Even so, there is still a variable portion of marine organic mass that is emitted as PMA. PMA is composed mainly of sea salt and organic aerosol mass, and it accounts for a small number of marine particles but a significant fraction of the total aerosol mass due to large sizes $(0.05-10 \mu \mathrm{m})$ (Grythe et al., 2014). PMA formation is driven by wave breaking and bubble bursting, which are primarily controlled by the surface wind speed (de Leeuw et al., 2011; Modini et al., 2015; Thorpe, 1992). While PMA typically accounts for a low fraction of the marine particle CCN concentration (Fossum et al., 2018; Quinn et al., 2017, 2019), a recent modeling study validated with observations suggests that PMA particles regulate secondary particle contributions to $\mathrm{CCN}$ over the remote MBL (Fossum et al., 2020). Enhanced condensation of water vapor onto these coarse-mode PMA particles can reduce in-cloud supersaturations, preventing the activation of smaller Aitken-mode particles. PMA is short-lived, with the largest PMA having deposition velocities several orders of magnitude greater than accumulation-mode particles (Petroff and Zhang, 2010; Pryor and Barthelmie, 2000; Williams et al., 2002), indicating that aerosol mass gained through gas-to-particle conversion onto PMA is quickly removed from the atmosphere. During the NAAMES campaigns, PMA contributions to $\mathrm{CCN}$ concentrations at $0.1 \%$ supersaturation were found to be low for the North Atlantic (averaging 14\%-31\% for all but the late autumn NAAMES campaign) (Quinn et al., 2019). Similarly, in global models, PMA was shown to account for about $20 \%-40 \%$ of CCN in the North Atlantic (Pierce and Adams, 2006; Yu and Luo, 2009). These observations indicate that a substantial fraction is likely from secondary biogenic sources or from continental sources. Meskhidze and Nenes (2006) reported that cloud droplet number concentrations were doubled over a phytoplankton bloom relative to the surrounding area. Several other studies have also shown that ocean productivity 
and biomass abundance relate to the spatial and temporal variability in MBL particle and cloud droplet concentrations (McCoy et al., 2015; Meskhidze and Nenes, 2010; Vallina et al., 2006). While sulfate is more hygroscopic than organic aerosol mass, the latter still contributes to the particle size (which lowers the Kelvin effect) and may decrease the surface tension (Frossard et al., 2018; Ovadnevaite et al., 2017). Organics are likely to contribute to $\mathrm{CCN}$ concentrations considering that organics often account for a significant fraction of marine Aitken- and accumulation-mode particle mass.

Linking aerosol and cloud properties to marine emissions is complicated by the influence of ship emissions and aerosols transported from the continents, including biomassburning smoke (Coggon et al., 2012; Shank et al., 2012; Yang et al., 2016). Continental pollution and DMS-derived sulfate lofted into the free troposphere can lead to long-range transport of particles and subsequent re-entrainment of these particles back into the MBL in a different location (Clarke et al., 2013; Dzepina et al., 2015; Korhonen et al., 2008; Quinn et al., 2019; Saliba et al., 2020; Shank et al., 2012). It is also known that DMS can persist over significant transport distances and contribute to secondary aerosol production in locations that are spatiotemporally removed from the source region (Mungall et al., 2016). Similarly, Zavarsky et al. (2018) show that measured and calculated isoprene and PMA fluxes positively correlate with upwind satellite aerosol measurements. Marine particle concentrations have also been shown to negatively correlate with precipitation along the air mass history given the role of precipitation scavenging as a prominent aerosol loss process (Andronache, 2004; Pruppacher and Klett, 1997; Sanchez et al., 2021; Vallina et al., 2006). Observations of new particle formation events correspond with precipitation over the air mass history, likely due to a decrease in coarse-mode aerosol concentrations and total particle surface area with precipitation scavenging (Andronache, 2004; Ueda et al., 2016).

Previous literature hints that phytoplankton activity is related to emissions of organic and sulfate aerosol mass precursors (Altieri et al., 2016; Arnold et al., 2010; Ayers et al., 1997; Bates et al., 1998b; Brüggemann et al., 2018; Ceburnis et al., 2011; Facchini et al., 2008; Hallquist et al., 2009; Hu et al., 2013; Huang et al., 2018a; Mansour et al., 2020; Ovadnevaite et al., 2014; Park et al., 2017; Quinn et al., 2019; Sanchez et al., 2018). These precursors are emitted over a large area at varying rates due to the spatial and temporal variation of marine biological activity (Behrenfeld, 2010; Behrenfeld and Boss, 2018). The MBL residence time and transport need to be accounted for to study the effect of this area source on particle concentrations and composition. The goal of this work is to look for correlative connections between measured aerosol loading and composition with ocean biology, physical ocean characteristics, and atmospheric boundary layer meteorology to identify the influence of upwind processes and biology on particulate mass formation. We use the state-of-the-art FLEXible PARTicle
(FLEXPART) trajectory model to identify the contribution of continental transport and to evaluate the connection between North Atlantic aerosols and potential explanatory variables weighted by air mass history and boundary layer residence time.

\section{Methods}

Here, we describe the measurements made onboard the R/V Atlantis during NAAMES as well as the satellite and model data products that we explore as explanatory variables. Analysis details, including filtering criteria, are also discussed.

\subsection{R/V Atlantis measurements during NAAMES}

The NAAMES campaigns were conducted on the R/V Atlantis over the four major periods of the North Atlantic marine phytoplankton cycle, aligning with the phytoplankton biomass minimum (November 2015, NAAMES1), maximum (May-June 2016, NAAMES2), and the transitions marked by the decay of biomass (September 2017, NAAMES3) and accumulation of biomass (March 2018, NAAMES4). Gray lines in Fig. 1a-d show the ship track for each campaign. A detailed description of each NAAMES campaign can be found in Behrenfeld et al. (2019).

Aerosols were sampled on the forward $\mathrm{O} 2$ deck of the $\mathrm{R} / \mathrm{V}$ Atlantis with a temperature-controlled isokinetic inlet approximately $18 \mathrm{~m}$ above sea level. Particles were dried in diffusion driers before being measured by instruments. Supermicron particles were sized with an aerodynamic particle sizer (APS 3321, TSI Inc., St. Paul, MN; size range 0.5$20 \mu \mathrm{m})$. Additional aerosol instrumentation was downstream of a $1.0 \mu \mathrm{m}$ sharp cut cyclone (SCC 2.229, BGI Inc. US) to measure only the submicron aerosol fraction. A condensation particle counter (CPC 3010, TSI Inc., St. Paul, MN) was used to measure particle number concentrations. A scanning electrical mobility sizer (SEMS, model 138, 2002, BMI, Hayward, CA) measured particle size distributions $(0.02-0.9 \mu \mathrm{m}$ diameter) at 5 min intervals utilizing a CPC (CPC 3025, TSI Inc., St. Paul, MN) to count the number of particles in each size bin of the aerosol size distribution. Because the SEMS CPC uses liquid to grow the particles large enough to be optically counted, the particle number concentrations measured by the CPC are commonly referred to as condensation nuclei or CN. Particle concentrations for diameters greater than and less than $100 \mathrm{~nm}\left(N_{>100 \mathrm{~nm}}, N_{<100 \mathrm{~nm}}\right)$ are derived from merged SEMS and APS particle size distributions. A single-particle soot photometer (SP2, DMT, Boulder, CO) measured refractory black carbon mass concentration. Submicron particles were analyzed with a high-resolution timeof-flight aerosol mass spectrometer (AMS, Aerodyne Research Inc., Billerica, MA) (DeCarlo et al., 2006) that measures non-refractory inorganic (sulfate, ammonium, nitrate, chloride) and organic components. The AMS does not ef- 

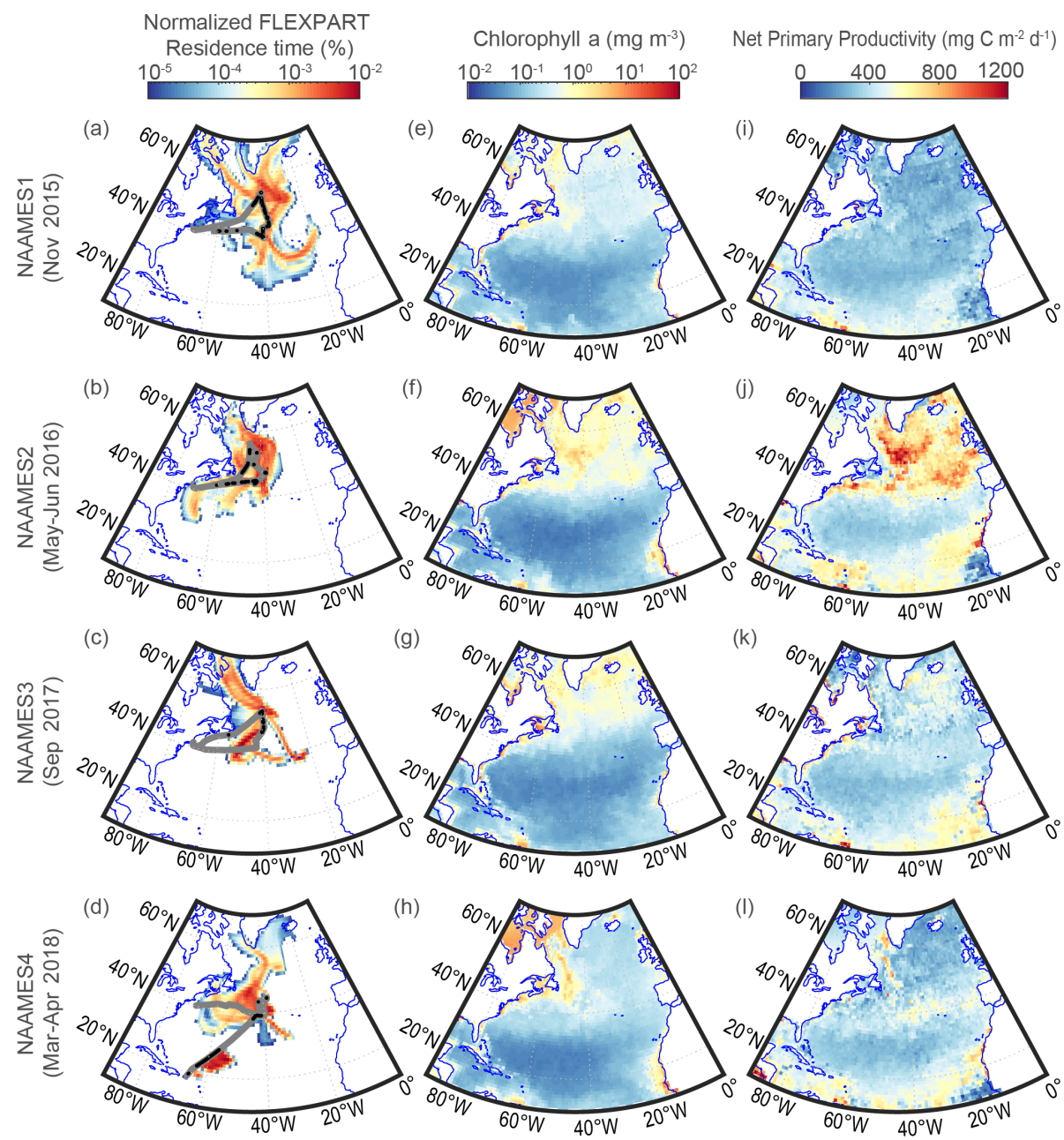

Figure 1. (a-d) The residence time fraction of all marine $5 \mathrm{~d}$ FLEXPART back trajectories column-integrated and normalized by the total residence time, $(\mathbf{e}-\mathbf{h})$ average satellite chlorophyll $a$, and (i-l) average CAFE-modeled net primary production for each NAAMES campaign. The gray line in (a)-(d) shows the R/V Atlantis cruise track, while the black points are initialization points for the back-trajectory model runs that satisfy the clean marine filter criteria (Sect. 2.6).

ficiently measure refractory particles (i.e., particles that do not efficiently vaporize at $600^{\circ} \mathrm{C}$ ), such as sea salt particles. The PMA particle number concentration is determined by integrating the fitted coarse mode of the SEMS and APS merged particle size distribution (Modini et al., 2015; Saliba et al., 2019). Radon was measured with a dual-flow-loop two-filter 103 radon detector (Whittlestone and Zahorowski, 1998). Continuous DMS measurements were made by atmospheric pressure chemical ionization mass spectrometers (Bell et al., 2013, 2015). One instrument collected air measurements, while the other analyzed gas exiting the seawater equilibrator. In-line chlorophyll $a$ measurements are calculated from AC-S hyper-spectral spectrophotometer measurements (WET Labs, Inc., Philomath, OR) using the "line height" method, which relates the phytoplankton absorption at $676 \mathrm{~nm}$ to chlorophyll $a$ from high-pressure liquid chromatography samples collected during NAAMES (Boss et al., 2013). In-line particulate organic carbon is derived from beam attenuation data with the AC-S spectrometer (Boss et al., 2013). A time series of key aerosol and DMS measurements is shown in Fig. S1 in the Supplement for each NAAMES campaign.

\subsection{Satellite data products}

Several biological parameters are obtained from merged satellite ocean color products derived by the GlobColour project (Maritorena et al., 2010). In this paper, four GlobColour level-3 satellite products, related to phytoplankton biomass, represent biological processes at $1^{\circ}$ horizontal resolution. The first is chlorophyll $a$, a primary photosynthetic pigment in phytoplankton. Chlorophyll $a$ is commonly used as a proxy for the biomass of phytoplankton (Behrenfeld et al., 2016; Lyngsgaard et al., 2017; Meskhidze and Nenes, 2010; Pastor et al., 2013). The GlobColour project has sev- 
eral different chlorophyll $a$ products that are derived from different methods. In this study we use the chlorophyll $a$ product derived from the Garver-Siegel-Maritonena ocean color model (Maritorena and Siegel, 2005). This specific chlorophyll $a$ product is chosen because the daily average product best correlates with in-line chlorophyll $a$ measurements $(r=0.87$; Table S7, Fig. S2). Figure 1e-h show the merged satellite-derived chlorophyll $a$ concentration over the North Atlantic averaged for each NAAMES campaign. For this study chlorophyll-normalized VOC production rates were not considered because of the large variability in observed values (Booge et al., 2016) and the overall unknown contributions from various VOC species to marine particle mass concentrations. The next biological parameter studied is marine particulate organic carbon, which is an important component in the carbon cycle that forms through photosynthesis and subsequent ecosystem processes. In-line particulate organic carbon also correlates with the satellite product $(r=0.70$; Table S7, Fig. S2). The absorption coefficient of colored detrital organic material (CDM) is also used as a parameter. This absorption coefficient is largely associated with chromophoric dissolved organic matter (CDOM), which is the fraction of dissolved organic matter that interacts with solar radiation (Nelson and Siegel, 2013). CDOM is also a photosensitizer in the photolysis of DMS, meaning CDOM generates reactive species upon the absorption of solar radiation that remove seawater DMS through oxidation (Bouillon and Miller, 2004; Brimblecombe and Shooter, 1986; Toole et al., 2003, 2008). The final parameter, the depth of the euphotic zone, represents the depth at which downwelling irradiance is $1 \%$ of the value at the surface. This depth roughly characterizes the layer of the ocean that can support net phytoplankton photosynthesis but is also a function of chlorophyll $a$ (Morel et al., 2007).

Even though in-line measurements correlate better with $1 \mathrm{~d}$ average products (Fig. S2), we used $8 \mathrm{~d}$ average products for all analyses because of the improved spatial coverage (reduced interference from clouds). The $8 \mathrm{~d}$ averages have about $\sim 45 \%$ more spatial coverage than $1 \mathrm{~d}$ averages and approximately $15 \%$ less coverage than monthly averages (Maritorena et al., 2010). If a grid cell is missing data for satellite-derived biological parameters, it is filled by averaging the surrounding eight grid cells. If all surrounding grid cells have missing data, then the next and previous $8 \mathrm{~d}$ averages are averaged together to fill the grid cell. This method sufficiently filled all missing data points.

\subsection{Modeled net primary production}

Net primary production is the formation of organic material through photosynthesis by phytoplankton. This process and correlated changes in other ecosystem rates lead to the emission of biogenic VOCs at the sea surface (Li et al., 2018). In general, net primary production is a function of the photosynthetically available radiation, the euphotic zone depth, the phytoplankton concentration, and the efficiency with which carbon biomass is formed (Silsbe et al., 2016). A number of different models calculate net primary production, but in this study we focus on net primary production derived from the Carbon, Absorption, and Fluorescence Euphoticresolving (CAFE) model, which has been shown to be the most accurate in a recent study (Silsbe et al., 2016). The model products are derived from merged satellite data from the Making Earth Science Data Records for Use in Research Environments (MEaSUREs) NASA initiative (Vollmer et al., 2011). Figure 1i-1 show CAFE-modeled net primary production over the North Atlantic averaged for each NAAMES campaign.

\subsection{GDAS model reanalysis data products}

The Global Data Assimilation System (GDAS, ftp://arlftp. arlhq.noaa.gov/pub/archives/gdas1/, last access: 10 February 2019) gridded output is used to initialize the Global Forecast System (GFS) model with observations obtained from surface observations, radiosondes, wind profilers, aircraft, buoys, radar, and satellites. Here, we use the $3 \mathrm{~h}$ GDAS $1^{\circ}$ resolution horizontal sea surface wind speed, low-level cloud cover, $3 \mathrm{~h}$ downward shortwave forcing (DSWF), and $6 \mathrm{~h}$ accumulated precipitation over the North Atlantic to identify the state of the MBL upwind of the R/V Atlantis.

\subsection{FLEXPART back trajectories}

The FLEXible PARTicle (FLEXPART) dispersion model is a Lagrangian particle dispersion model used to estimate transport pathways of observed air samples (Owen and Honrath, 2009; Stohl et al., 2005; Zhang et al., 2014). Here, we use the FLEXPART model to connect the R/V Atlantis observations (Sect. 2.1) to the explanatory variables discussed in Sect. 2.2-2.4 by weighting the explanatory variables by the FLEXPART air mass residence time. For the NAAMES campaigns, $10 \mathrm{~d}$ FLEXPART backward simulations are initialized along the path of the R/V Atlantis every hour. The GFS and its "final analysis" drive all the simulations with $3 \mathrm{~h}$ temporal resolution, $1^{\circ}$ horizontal resolution, and 26 vertical levels that cover the depth of the troposphere and extend into the stratosphere. In each simulation, 10000 passive particle tracers are released at the ship location. The advection and dispersion of the particles are simulated backwards in time. The product is an upwind spatial distribution of the particle residence times (average time an air parcel stays within a model grid cell). Figure 1a-d show the residence time integrated over all 26 vertical levels for the first $5 \mathrm{~d}$ of all the FLEXPART trajectories during clean marine periods (Sect. 2.6). The residence time in Fig. 1a-d is normalized by the total residence time of all clean marine trajectories to show the residence time fraction over each grid cell during each NAAMES campaign. For the remaining analysis in this paper, the vertical structure of the residence time is column- 
integrated over only the vertical levels that are completely or partially within the MBL based on GDAS MBL heights. Remaining vertical levels were excluded from analysis.

\subsection{Criteria for clean marine conditions}

In order to constrain the impact of meteorological and biological parameters on marine particle chemical composition and concentration, air masses that are influenced by continental and anthropogenic emissions are excluded from the analysis. "Clean marine" conditions are defined as periods when (1) total particle number concentrations are below $1000 \mathrm{~cm}^{-3}$, (2) black carbon mass is below $50 \mathrm{ng} \mathrm{m}^{-3}$ to filter out ship contamination and continental transport (Betha et al., 2017; Saliba et al., 2020), (3) radon, a continental tracer, is below $500 \mathrm{mBq} \mathrm{m}^{-3}$, (4) AMS non-refractory organic aerosol mass is less than $0.5 \mu \mathrm{g} \mathrm{cm}^{-3}$ as suggested by prior measurements of organic aerosol mass over the marine environment (Russell et al., 2010), and (5) less than $25 \%$ of the $5 \mathrm{~d}$ FLEXPART back-trajectory residence time passes over continents. Figure 2 shows the fraction of the FLEXPART trajectory time over land for $6 \mathrm{~h}$ to $10 \mathrm{~d}$ trajectories and indicates that the median fraction for the $5 \mathrm{~d}$ back trajectory is $25 \%$, so half of the $2236 \mathrm{~h}$ of measurements are removed due to this criterion alone. In the end, 557 samples are representative of clean marine conditions. Despite meeting the clean marine criteria, black carbon mass still moderately $(r=0.51)$ correlates with AMS non-refractory organic and sulfate aerosol mass (Fig. S3). The correlation even holds at significantly lower black carbon mass concentration thresholds, which is similar to previous findings (Huang et al., 2018b; Saliba et al., 2020; Shank et al., 2012), signifying that long-range transport or ship emissions contribute to organic aerosol mass concentrations even in the cleanest remote marine environments. However, approximately $75 \%$ of the variability in the organic and sulfate aerosol mass is still unaccounted for, indicating a potential influence from marine biogenic sources.

\section{Results and discussion}

An example of the MBL column-integrated residence time of individual FLEXPART back trajectories is shown in Fig. 3a. This is then normalized and multiplied by the biological ( $8 \mathrm{~d}$ average) or meteorological ( 3 or $6 \mathrm{~h}$ average) explanatory variables (for example, satellite-derived chlorophyll $a$ shown in Fig. 3b) to obtain a residence-time-weighted value that, when integrated, represents the average value over the back trajectory. An example of the residence-time-weighted chlorophyll $a$ is shown in Fig. 3c. Higher values in Fig. 3c represent regions where chlorophyll $a$ had the greatest influence on the air mass intercepted by the ship due to the corresponding high residence times (Fig. 3a) and high chlorophyll $a$ concentrations (Fig. 3b) in these regions. The equation be-

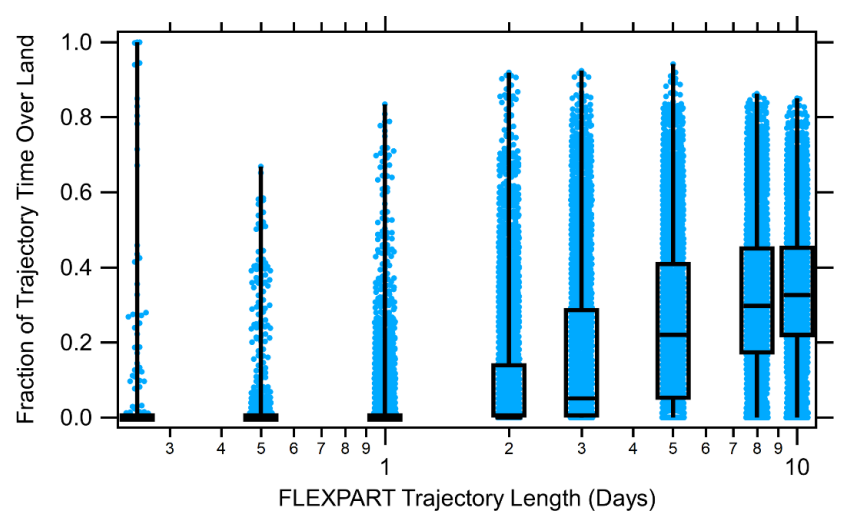

Figure 2. Box plot of air mass residence time fraction spent over land for FLEXPART back trajectories of $6 \mathrm{~h}$ to $10 \mathrm{~d}$ for all cases (both marine and continental back trajectories). Blue points represent each individual FLEXPART back trajectory. The horizontal lines show the 25th, 50th, and 75th percentiles for the fraction of trajectory time over land, and the vertical lines represent the range.

low describes the explicit calculation of the residence-timeweighted explanatory variables.

Integrated residence-time-weighted explanatory variable

$$
=\frac{\sum_{t=1}^{T} \sum_{\text {long }=1}^{360} \sum_{\text {lat }=1}^{180} R_{t, \text { long, lat }} E_{t, \text { long, lat }}}{\sum_{t=1}^{T} \sum_{\text {long }=1}^{360} \sum_{\text {lat }=1}^{180} R_{t, \text { long, lat }}}
$$

Here, $R_{t, \text { long,lat }}$ and $E_{t, \text { long, lat }}$ are the MBL residence time and explanatory variable values, respectively, at each hour $(t)$, longitude (long), and latitude (lat) for a FLEXPART back trajectory with a length of $T$ hours. Weights are applied evenly at all trajectory times. Residence time over land is excluded from the integration of weighted trajectories. For satellite and modeled biological variables, an $8 \mathrm{~d}$ average is necessary to obtain sufficient measurement spatial coverage (Sect. 2.2). While not ideal, an $8 \mathrm{~d}$ average is still useful because the phytoplankton cycle is fairly slow (1 year) relative to the frequency of meteorological disturbances (days), and consequently the low variation from one $8 \mathrm{~d}$ average in chlorophyll $a$ values to the next indicates that an $8 \mathrm{~d}$ average is appropriate (Fig. S5). In addition, advection is slower in the ocean as ocean currents are significantly slower than atmospheric wind speed.

Weighted FLEXPART back trajectories are compared to particle properties and atmospheric DMS concentrations measured aboard the R/V Atlantis. We define correlation strength by the calculated Pearson's coefficient $(r)$ following Devore and Berk (2012), where $|r|<0.25$ indicates that there is no correlation, $0.25 \leq|r|<0.50$ is defined as a weak correlation, $0.50 \leq|r|<0.80$ is defined as a moderate correlation, and $|r| \geq 0.80$ is defined as a strong correlation. All presented Pearson's correlation coefficients are statistically 

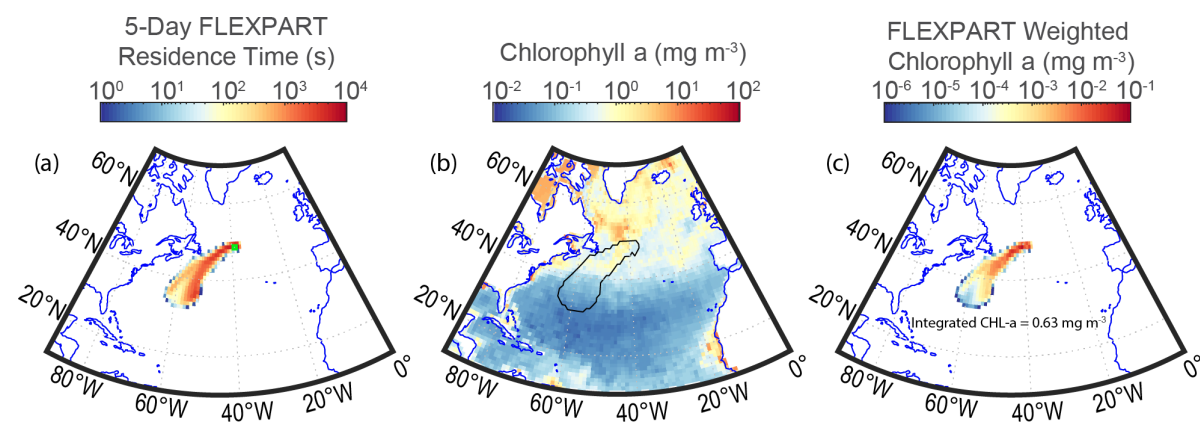

Figure 3. (a) An example 5 d FLEXPART trajectory (MBL column-integrated) residence time distribution from the NAAMES2 campaign initialized at $00 \mathrm{Z}$ on 19 May 2016 and the ship location, shown by the green square. (b) Satellite chlorophyll $a$ product and an outline of the $5 \mathrm{~d}$ FLEXPART back trajectory. (c) Satellite-derived chlorophyll $a$ weighted by the $5 \mathrm{~d}$ FLEXPART residence time and then integrated to obtain a value representative of the level of influence chlorophyll $a$ may have had over the past $5 \mathrm{~d}$ on the air mass measured at the R/V Atlantis location.

significant $(p<0.05)$. For consistency, we have assumed that the relationships between variables will be linear. Correlations of trajectories weighted by biological and meteorological parameters with measured aerosol mass, number, and DMS concentrations vary by the length of the weighted trajectory (Fig. 4, Tables S8-S16). In particular, many of these correlations increase with increasing trajectory length, indicating that biological and meteorological processes over the air mass history are influential for measured particle properties and that using only spatially contemporaneous data would miss correlative connections that are lagged in time. Over longer trajectories, the weighted parameter is less likely to be related to the local value because the trajectories cover more ocean surface area, and thus they are more likely to be weighted by both high and low values (for example, chlorophyll $a$ in Fig. 3b). However, there are still cases when a long (5d) trajectory is consistently weighted by low values or high values, which may lead to extremes in particle concentrations or composition, depending on the effect of the explanatory variable. In the following sections, the correlation strength is interpreted based on known sources and sinks of marine particles and DMS.

\subsection{Biological controls on marine aerosols}

Measured non-refractory organic aerosol mass correlates weakly with FLEXPART residence-time-weighted chlorophyll $a$, with the highest correlation at $2 \mathrm{~d}$ trajectory lengths $(r=0.39$; Figs. 4a, 5a). The correlation of organic aerosol mass with chlorophyll $a$ is similar for CDM $(r=0.32)$, but there is no correlation with seawater particulate organic carbon or the euphotic zone depth $(|r|<0.25)$. Organic aerosol mass correlates moderately with trajectoryweighted CAFE-modeled net primary production for 2 to $5 \mathrm{~d}$ trajectories $(r=0.54-0.62)$ (Figs. 4a, 5b, Table S8). Comparisons of non-refractory organic aerosol mass with other net primary production models are shown in the Supplement in Table S8. These results suggest that a substantial por- tion of non-refractory organic mass is from secondary biogenic VOC emissions, such as MSA, isoprene and monoterpenes, and other unidentified biogenic VOCs (Altieri et al., 2016; Hallquist et al., 2009; Zorn et al., 2008). Nonrefractory organic aerosol mass also correlates with downward shortwave forcing (DSWF), with correlation strength increasing at longer trajectory lengths (Figs. 4a, 5c). Increased solar radiation promotes photosynthesis by phytoplankton and is necessary for photochemical production of secondary organic aerosol. Biogenic VOC emissions (precursors of particle-phase organic mass) are a by-product of photosynthesis (Dani and Loreto, 2017) and likely cause part of the correlation of organic aerosol mass with DSWF. Even though DSWF moderately correlates with organic aerosol mass concentrations ( $r=0.52$ at $2 \mathrm{~d}$ trajectories), the presence of phytoplankton is necessary for photosynthetic biological emissions to occur (Silsbe et al., 2016). Figure 5c notably shows that DSWF is often higher during NAAMES4 (March-April 2018) compared to the other campaigns. However, NAAMES4 has lower measured organic aerosol mass concentrations, particularly when compared to the late spring campaign (NAAMES2, May-June 2016). The higher DSWF during much of NAAMES4 is simply due to the fact that the NAAMES4 campaign extended further to the south (to $\sim 20^{\circ} \mathrm{N}$; Fig. 1d) than any of the other campaigns. The relatively low abundance of phytoplankton biomass in the tropical Atlantic, compared to the subarctic Atlantic (shown by chlorophyll $a$ concentrations; Fig. 1f, h, j, l), results in lower levels of photosynthesis and therefore lower VOC emissions and organic aerosol mass formation. The amount of photosynthesis taking place depends on both the DSWF and phytoplankton abundance, both of which are included in the calculation of net primary production (in addition to other parameters; Sect. 2.3). Consequently, the phytoplankton net primary production is a better predictor of marine biogenic organic aerosol mass and likely biogenic VOC emissions than 


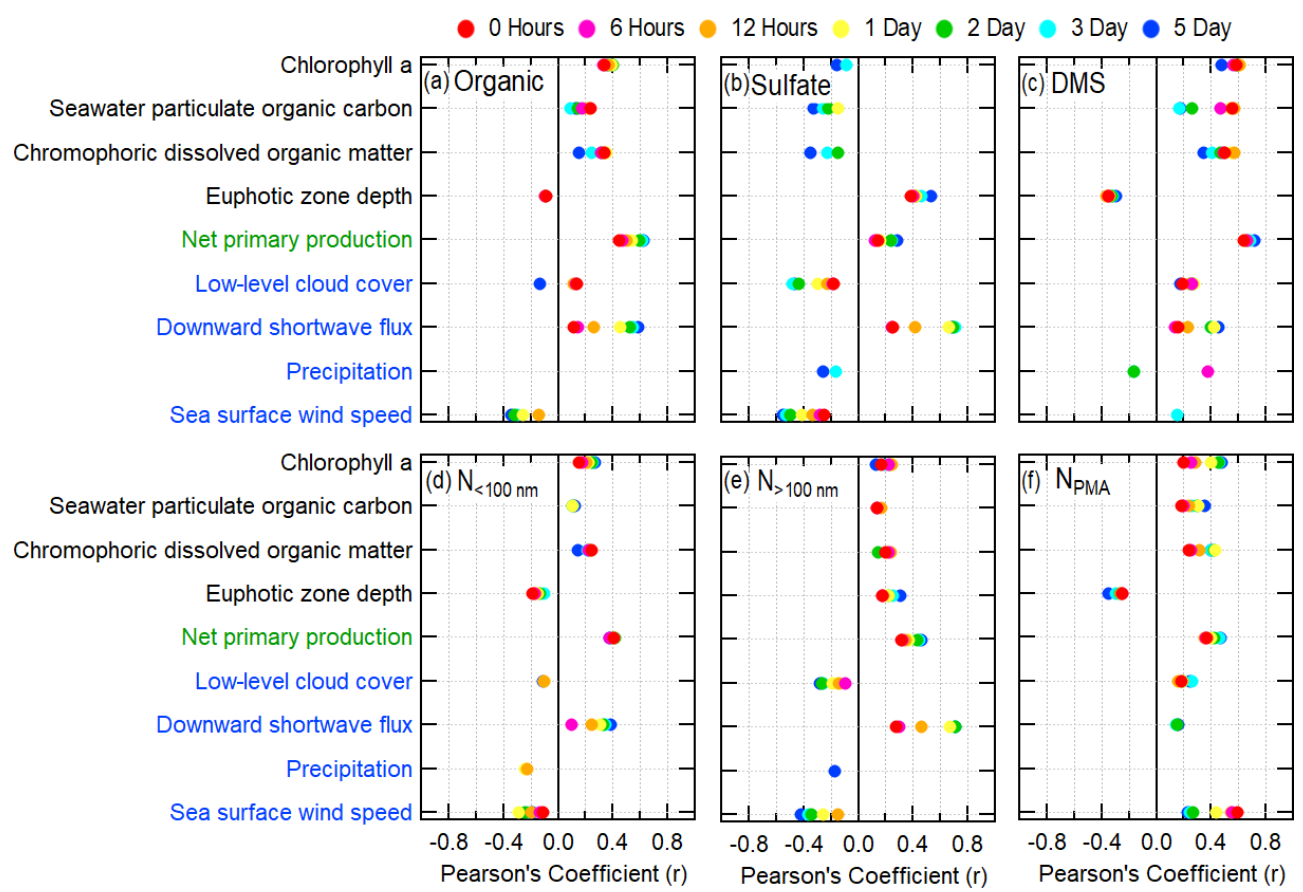

Figure 4. Pearson's correlation coefficients between FLEXPART residence-time-weighted explanatory variables and the following atmospheric measurement variables: (a) organic aerosol mass, (b) sulfate aerosol mass, (c) DMS, (d) particle number concentration for diameters $<100 \mathrm{~nm}$, (e) particle number concentration for diameters $>100 \mathrm{~nm}$, and (f) PMA-mode concentration. The explanatory variables listed on the ordinate axis are colored to denote satellite-derived parameters (black text), CAFE ocean biology model parameters (green text), and atmospheric model reanalysis products (blue text). The PMA-mode number concentration is derived from the SEMS and APS instruments on the R/V Atlantis. Pearson's correlation coefficients are only included for statistically significant cases in which $p<0.05$.

DSWF, chlorophyll $a$ biomass, or any other individual biological parameter.

In contrast, the measured sulfate aerosol mass concentration has a weak correlation or no correlation with the satellite-measured biological parameters and modeled net primary production $(r<0.4)$, with the exception of the euphotic zone depth ( $r=0.53$ for $5 \mathrm{~d}$ trajectory), even though the main marine biogenic source of sulfate aerosol is the oxidation of VOC emissions from phytoplankton, specifically DMS (Ayers and Gras, 1991; Bates et al., 1998a, 2012; Covert et al., 1992; Quinn et al., 2000; Rinaldi et al., 2010; Sanchez et al., 2018). Measured atmospheric DMS concentrations moderately correlate with biological parameters for short trajectories $(0-6 \mathrm{~h})$; however, this correlation is driven solely by a few measurements made during the bloom phase of the phytoplankton cycle (NAAMES2, Fig. 6). Excluding the measurements from NAAMES2 would result in no significant correlation between measured atmospheric DMS and biological parameters. Significantly higher chlorophyll $a$ concentrations and net primary production rates are present during the NAAMES2 phytoplankton bloom, causing the significantly higher DMS concentrations (Fig. 1e-1). The DMS correlation with chlorophyll $a$ during the bloom period is consistent with results from similar analyses performed by Arnold et al. (2010) and Park et al. (2018), wherein DMS measurements were collected in the South Atlantic and Arctic, respectively. Unlike atmospheric DMS, DMS in seawater correlates moderately with the modeled net primary production even when excluding NAAMES2 $(r=0.54)$. This difference is driven by variability in the fraction of seawater DMS that is released into the atmosphere. In addition, DMS production is highly dependent on phytoplankton species (Keller, 1988), complicating the relationship between atmospheric DMS measurements and bulk ocean quantities as well as confounding direct correlations.

In addition, atmospheric DMS and non-refractory sulfate aerosol mass are observed to have little to no correlation with each other $(r=0.34)$ or with ocean biological activity. This lack of correlation may be due to the longer DMS atmospheric lifetime relative to biogenic VOCs (Kloster et al., 2006; Sciare et al., 2001). For a typical average $\mathrm{OH}$ radical concentration of $0.6 \mathrm{ppt}$, the lifetime of DMS is approximately $37 \mathrm{~h}$, which is much longer compared to the lifetime of known marine biogenic VOCs, such as isoprene $(1.8 \mathrm{~h})$ and monoterpenes (tens of minutes to $3 \mathrm{~h}$ depending on the species) (Atkinson and Arey, 2003; Lee et al., 2006; Liakakou et al., 2007; Pandis et al., 1995; Seinfeld and Pandis, 2006). Also, $\mathrm{SO}_{2}$, a DMS oxidation product, has a lifetime on the order of days to weeks. Organic aerosol mass likely correlates with sea surface biomass and net primary produc- 

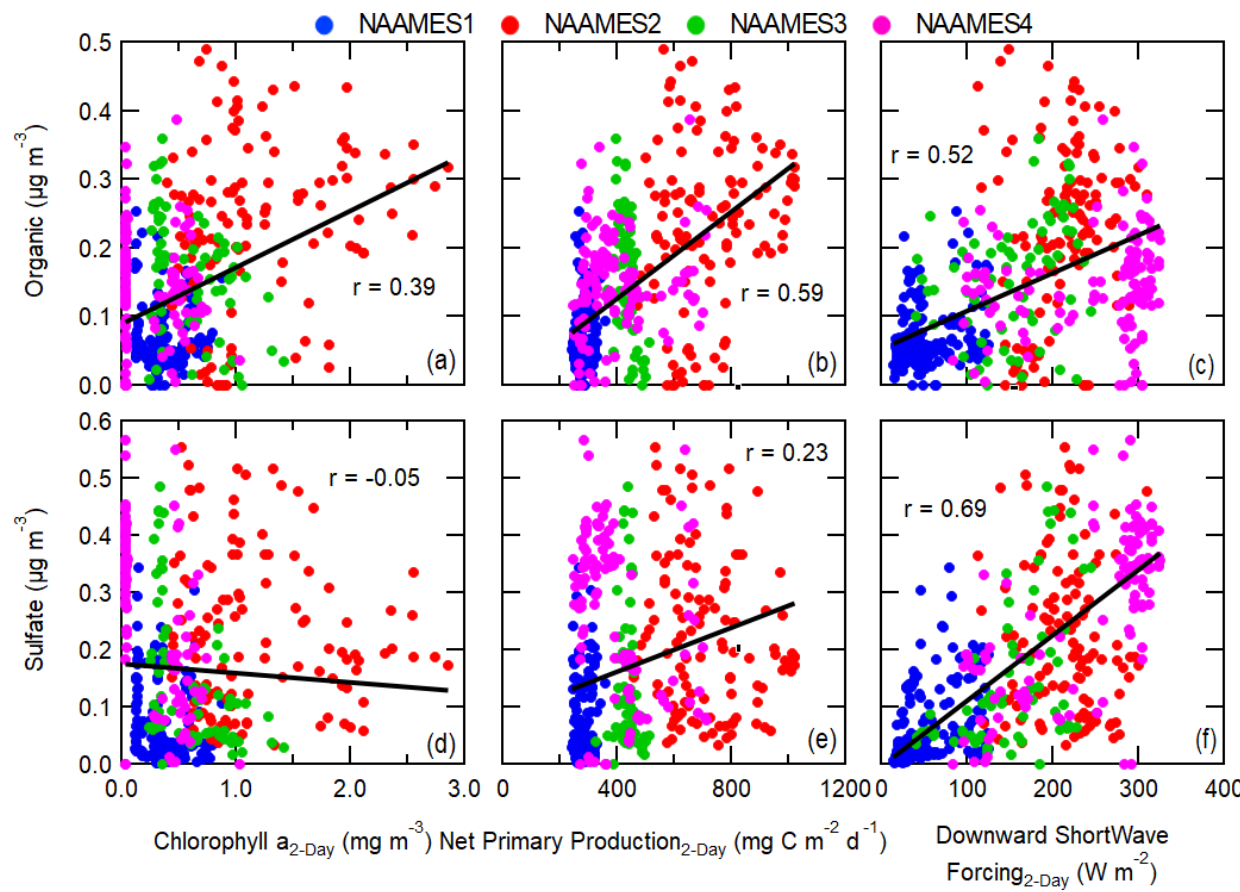

Figure 5. Measured atmospheric concentrations of (a-c) organic and (d-f) sulfate aerosol mass compared to 2 d FLEXPART residence-timeweighted satellite chlorophyll $a$, modeled net primary production, and reanalysis model downward shortwave forcing. Pearson's coefficients $(r)$ are included for each plot along with best-fit lines shown as black lines.
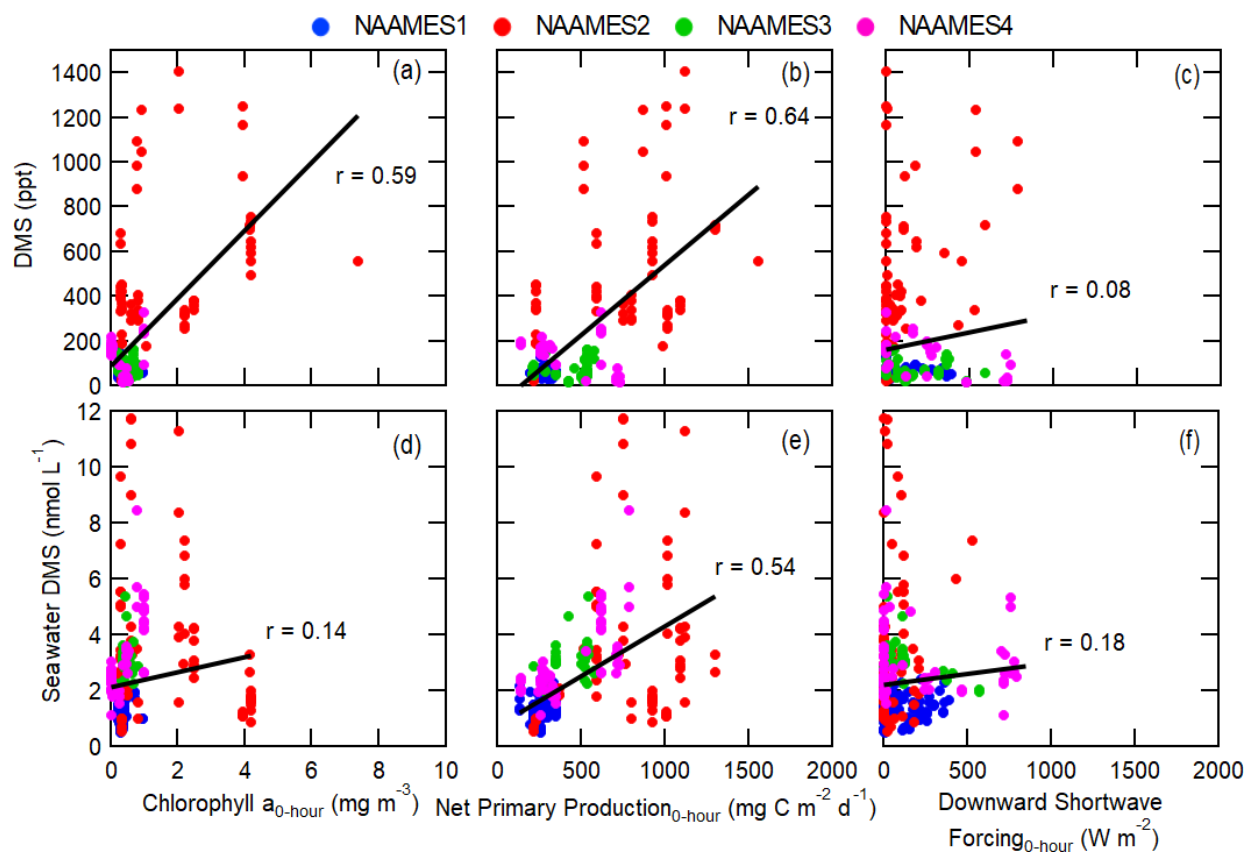

Figure 6. Measurements of (a-c) atmospheric and (d-f) in-water DMS concentrations compared to R/V Atlantis measurements of chlorophyll, net primary production, and downward shortwave forcing. Pearson's coefficients $(r)$ are included for each plot along with best-fit lines shown as black lines. 
tion more than sulfate aerosol mass, partially because of the shorter lifetime. Once emitted, DMS and its oxidation products can be advected large distances or become lofted into the free troposphere (Clarke et al., 2013; Korhonen et al., 2008; Russell et al., 1998; Sanchez et al., 2018; Thornton et al., 1997), where the resulting sulfate aerosol is not sampled by the ship. DMS also has a number of chemical pathways with various secondary aerosol yields, making a direct link to biological processes more challenging (Faloona et al., 2009). For these reasons, biomass and net primary production are not good predictors of DMS (Gunson et al., 2006). Organic aerosol mass precursors quickly condense onto existing particles to form secondary organic aerosol (SOA) soon after emission (Ehn et al., 2014; Liakakou et al., 2007; Wennberg et al., 2018).

Similar to organic aerosol mass concentrations, particle number concentrations have weak correlations with biomass abundance (Fig. 4d, e). Comparisons to particle number based on size are useful because they provide information on possible links to specific processes. The size distributions are split to derive integrated particle concentrations for diameters greater and less than $100 \mathrm{~nm}\left(N_{>100 \mathrm{~nm}} ; N_{<100 \mathrm{~nm}}\right.$; a rough delimiter between the Aitken- and accumulation-size modes) because of the differences in marine processes that contribute to changes in particle concentrations at different sizes. Specifically, Aitken-mode particle concentrations $\left(N_{<100 \mathrm{~nm}}\right)$ are strongly driven by new particle formation, which often occurs when total particle surface area is low (Humphries et al., 2015; Raes et al., 1997). In contrast, accumulation-mode particle concentrations $\left(N_{>100 \mathrm{~nm}}\right)$ are driven by the growth of the Aitken mode through cloud processing and condensation processes. $N_{>100 \mathrm{~nm}}$ particles weakly correlate with modeled net primary production ( $r=0.46$ for $5 \mathrm{~d}$ weighted back trajectories), moderately correlate with non-refractory organic masses $(r=0.65)$, and strongly correlate with sulfate masses $(r=0.83)$; this is expected since larger particles account for most of the total submicron particle mass measured by the AMS. Small particles contain much less mass, so $N_{<100 \mathrm{~nm}}$ particles have little to no correlation with the measured non-refractory organic $(r=0.21)$ and sulfate $(r=$ $0.39)$ mass. $N_{<100 \mathrm{~nm}}$ also has no correlations with chlorophyll $a(r<0.25)$. This result does not preclude a biological influence on $N_{<100 \mathrm{~nm}}$, but it demonstrates the limitations of this analysis in resolving some complex processes such as new particle formation. In addition, PMA concentrations correlate weakly with biomass abundance (Fig. 4f), indicating there may be a weak influence of phytoplankton activity on PMA number concentration, as shown previously (Saliba et al., 2019). Weak correlations between particle number or composition and net primary production suggest that other processes also influence particle concentrations. Possible meteorological influences are discussed in the following section.

\subsection{Meteorological controls on marine aerosols}

Meteorological parameters can also influence particle concentrations. In addition to being important for biological processes, DSWF is also important for initiating photochemical oxidation of biogenic VOCs, which leads to the formation of organic and sulfate aerosol mass (Altieri et al., 2016; Bates et al., 1998b; Frossard et al., 2014b; Hallquist et al., 2009; O'Dowd et al., 2002; Rinaldi et al., 2010; Sievering et al., 1992; Warren and Seinfeld, 1985). This process may cause the moderate correlation between sulfate aerosol mass and DSWF despite having no correlation with satellite biomass or modeled net primary production (Figs. 4, 5f). This also implies that DSWF is involved in both the photochemical oxidation of VOCs and photosynthesis of marine phytoplankton, and both processes likely strengthen the correlation of organic aerosol mass and DSWF. Figure 4 also shows how other meteorological parameters influence particle concentrations. For example, low-level cloud cover is shown to negatively correlate with sulfate aerosol mass and $N_{>100 \mathrm{~nm}}$. The presence of clouds will decrease the solar radiation reaching the ocean surface, which would contribute to a negative correlation between low-level cloud cover and sulfate and $N_{>100 \mathrm{~nm}}$, while aqueous production pathways would presumably result in a positive low-level cloud cover correlation with sulfate mass (Hoppel et al., 1986; Hudson et al., 2015; Pirjola et al., 2004; Sanchez et al., 2020). The negative correlation between low-level cloud cover and sulfate mass suggests that aqueous processing may be relatively less important than gas-phase photochemical mechanisms. Meteorological systems have consistent patterns, so, like low-level cloud cover and DSWF, many other meteorological parameters covary with each other, complicating linking the particle properties to specific meteorological processes. Table S5 indicates that DSWF correlates moderately or weakly with all the meteorological parameters considered from the GDAS dataset. In this section, we examine how the other meteorological parameters, shown in Fig. 4, also affect aerosol mass and number concentrations.

Sea surface wind speed negatively correlates with aerosol number and mass concentrations (Fig. 4), except for PMAsized particle number concentrations, and the correlation is increasingly strong for longer trajectory lengths. In order to understand the link between particle concentration and wind speed, it is important to recognize how wind speed may affect different particle formation processes (such as sea spray, particle growth, and particle formation). In contrast to submicron particle mass and number concentrations, sea surface wind speed positively correlates with PMA number concentrations (Figs. 4f, 8a) (Saliba et al., 2019). This correlation is highest $(r=0.59$ ) when only considering the wind speed at the ship location ( $0 \mathrm{~h}$ trajectories) and continuously decreases for longer back-trajectory lengths. This indicates that the shorter lifetime of PMA, due to the preferential sedimentation loss of larger particles, makes the history of the air 
mass irrelevant in this situation. The average dry PMA-mode diameter, determined with a coarse-mode fitting algorithm, was $0.54 \mu \mathrm{m}$ and as high as $1.12 \mu \mathrm{m}$ (Saliba et al., 2019), which is larger than Aitken- and accumulation-mode particles. Because PMA particles are large, they are more prone to rapid removal from the MBL through deposition relative to smaller particles (Pryor and Barthelmie, 2000). Specifically, at wind speeds greater than $10 \mathrm{~m} \mathrm{~s}^{-1}$ the depositiondependent lifetime of a $3 \mu \mathrm{m}$ wet-diameter particle in a $500 \mathrm{~m}$ MBL is about $3-12 \mathrm{~h}$, whereas the lifetime of a $0.1-1 \mu \mathrm{m}$ wet-diameter particle is several days to weeks.

While counterintuitive, the inverse correlation between $N_{>100 \mathrm{~nm}}$ and sea surface wind speed is likely driven by enhanced PMA concentrations at higher wind speeds that increase the pre-existing condensational sink for gas-toparticle conversion. PMA does not significantly contribute to total particle number concentrations (or $N_{>100 \mathrm{~nm}}$ ) and incidentally is often considered not to be a major driver of variability in cloud microphysics (Quinn et al., 2017). In a recent modeling study by Fossum et al. (2020), the authors showed evidence that the presence of elevated sea salt concentrations from PMA can indirectly affect cloud droplet concentrations by enhancing the uptake of water vapor at low supersaturations, causing a reduction of in-cloud maximum supersaturations. A smaller maximum supersaturation will lead to fewer small particles $\left(N_{<100 \mathrm{~nm}}\right)$ activating to form cloud droplets and hence fewer small particles growing through cloud processing to form large particles $\left(N_{>100 \mathrm{~nm}}\right)$. This feedback does not explain why non-refractory sulfate and organic aerosol mass are also moderately and weakly inversely proportional to wind speed, respectively, but they are also possibly linked to PMA concentrations. PMA concentrations are fairly low compared to $N_{>100 \mathrm{~nm}}$ and $N_{<100 \mathrm{~nm}}$ (Figs. 7c, d, 8a), but since PMAs are quite large, they account for a significant fraction of the total particle surface area. Figure $8 \mathrm{~b}$ shows that the total particle surface area moderately correlates with $6 \mathrm{~h}$ back trajectories weighted by sea surface wind speed $(r=0.51)$ and PMA frequently accounts for a majority of the total particle surface area. Since new particle formation occurs under conditions of low total particle surface area, the enhancement in total particle surface area at elevated sea surface wind speeds can prevent the occurrence of new particle formation (Cainey and Harvey, 2002; Yoon and Brimblecombe, 2002). However, new particle formation is more likely to occur in the free troposphere, independently of the MBL PMA concentration, and then be subsequently entrained into the MBL, possibly explaining the lack of correlation of $N_{<100 \mathrm{~nm}}$ with wind speed $(|r|=<0.25)$ (Clarke, 1993; Raes et al., 1997; Sanchez et al., 2018).

The negative correlation between non-refractory sulfate and organic mass with wind speed may be linked to the short depositional lifetime of coarse PMA relative to smaller particles. Secondary particles formed through the condensation of VOC oxidation products and sulfate onto PMA are likely quickly removed through deposition. Secondary sul- fate formation from $\mathrm{SO}_{2}$ occurs rapidly on fresh PMA particles via uptake due to aqueous ozone reactions (Sievering et al., 1992). Subsequently, in-cloud sulfate formation from $\mathrm{SO}_{2}$ continues by oxidation due to hydrogen peroxide (Jacob, 2000). Other factors associated with high wind speed conditions, such as coagulation, dry deposition, and enhanced vertical mixing, likely also contribute to the observed negative correlation between wind speed and particle concentration. In addition, some of the secondary organic and sulfate mass may be missed by the AMS measurements. The AMS is limited to measuring only non-refractory particles, so organic and sulfate aerosol mass that has condensed onto refractory PMA is less likely to be efficiently vaporized and measured (DeCarlo et al., 2006; Frossard et al., 2014a). Wind speed also inversely correlates with DSWF $(r=-0.65$, Table S5). As previously mentioned, DSWF is proportional to aerosol mass due to its stimulation of VOC emissions by marine biota and role in the photochemical oxidation of VOCs. Since meteorological variables covary, DSWF may partially drive the correlation strength between wind speed and aerosol mass concentrations or vice versa.

Precipitation is a well-known sink for aerosol number and mass concentrations (Croft et al., 2010; Stevens and Feingold, 2009). In addition, new particle formation events have been shown to correspond to precipitation during the air mass history, likely due to a decrease in large particle concentration and therefore total particle surface area because of precipitation scavenging (Andronache, 2004; Ueda et al., 2016). Despite this fact, precipitation was shown to have little to no correlation with aerosol number or mass (Figs. 4, S4; $r<0.40)$. This observation may partially reflect the precipitation data being a $6 \mathrm{~h}$ average GDAS product rather than direct measurements. Simulated precipitation estimates have been shown to only moderately correlate with measurements (Beck et al., 2019). Figure 7c and d show the relationship between sea surface wind speed and $N_{>100 \mathrm{~nm}}$ and $N_{<100 \mathrm{~nm}}$. In this figure, the points are colored based on the log of the $5 \mathrm{~d}$ trajectory average precipitation and they show that, in general, elevated precipitation amounts typically correspond to higher wind speeds. When compared directly, wind speed and precipitation are still only weakly correlated $(r=0.34$, Fig. S6), but this weak covariance indicates that the proposed links between elevated wind speeds and aerosol number and mass concentrations may also be partially driven by enhanced precipitation. Precipitation will likely also remove PMA; however, as shown in Fig. 4f, PMA concentration has the highest correlation with recent wind speed and decreases with longer back trajectories. Even though PMA may be removed by precipitation, it is also replenished quickly.

\section{Conclusions}

We studied the relationship between marine aerosols measured over the North Atlantic Ocean during NAAMES 

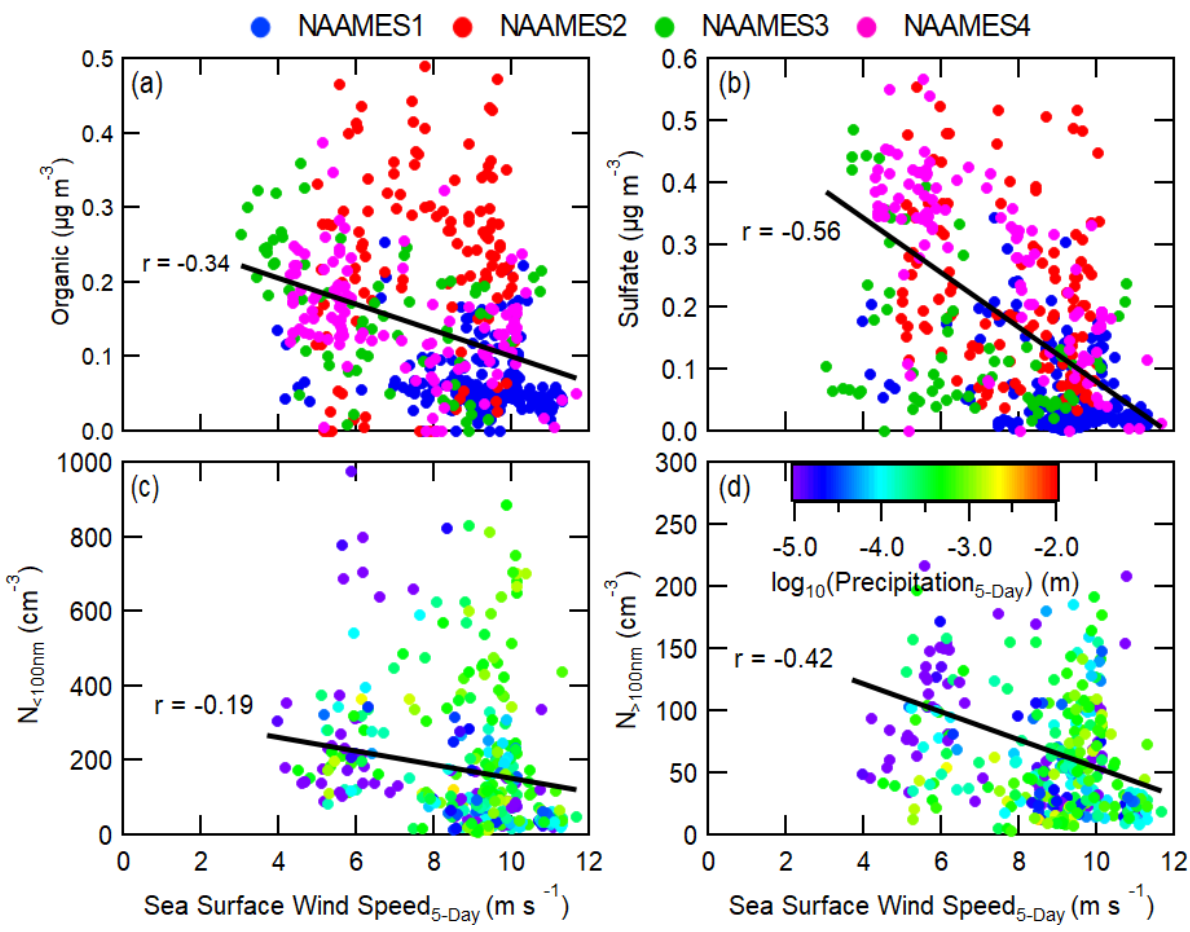

Figure 7. Measurements of atmospheric (a) organic aerosol mass, (b) sulfate aerosol mass, (c) number concentration for diameters $<100 \mathrm{~nm}$, and (d) number concentration for diameters $>100 \mathrm{~nm}$ compared to the $5 \mathrm{~d}$ FLEXPART residence-time-weighted model reanalysis wind speed. Points are colored based on the corresponding campaign in (a) and (b) and colored by the base-10 logarithm of the $5 \mathrm{~d}$ FLEXPART residence-time-weighted model reanalysis $6 \mathrm{~h}$ accumulated precipitation for $(\mathbf{c})$ and $(\mathbf{d})$. Pearson's coefficients $(r)$ are included for each plot along with best-fit lines shown as black lines.

and back trajectories weighted by four metrics of satellitemeasured biological and physical properties (chlorophyll $a$, seawater particulate organic carbon, colored detrital organic materials, euphotic zone depth), modeled net primary production, and model reanalysis meteorological parameters. Correlations between residence-time-weighted explanatory variables and aerosol measurements indicate that both biological and meteorological processes influence aerosol concentrations and composition. Specifically, non-refractory organic aerosol mass correlates weakly with chlorophyll $a$ concentration, a proxy for phytoplankton biomass, averaged over $2 \mathrm{~d}$ back trajectories $(r=0.39)$ and moderately with net primary production over $5 \mathrm{~d}$ trajectories $(r=0.62)$. In general, the satellite-derived chlorophyll $a$, absorption coefficient of colored detrital organic materials, seawater particulate organic carbon, and the euphotic zone depth moderately or strongly correlate with each other and therefore had similar relationships to observed particle properties. In addition, organic aerosol mass moderately correlated with DSWF, increasingly for longer trajectory lengths $(r=0.58$ at $5 \mathrm{~d}$ trajectories). These results indicate that organic aerosol mass is influenced by the VOC emissions encountered by the air mass, which are driven by biological activity. Sulfate aerosol mass only weakly correlates with marine net primary production $(r<0.50)$, even though marine non-sea-salt sul- fate aerosol mass is also derived from marine VOC emissions. This difference is attributed to the short lifetime of organic aerosol mass precursors, like isoprene and monoterpenes (minutes to hours), which were below detection limits during NAAMES, relative to sulfate aerosol mass precursors such as DMS (1-2d) (Kloster et al., 2006; Liakakou et al., 2007; Sciare et al., 2001) and DMS oxidation products such as $\mathrm{SO}_{2}$ (days to weeks) (Faloona et al., 2009). Furthermore, the longer lifetime of DMS and its oxidation products can delay the formation of sulfate aerosol mass, making sulfate precursors more likely to advect through long-range transport if vertically lofted into the free troposphere and reentrained down into the MBL. The MBL-to-free-troposphere transport of DMS is not captured well by the FLEXPART model. In addition, there are numerous DMS chemical pathways with various secondary aerosol yields that can obscure any link between sulfate aerosol concentrations and biogenic processes (Faloona et al., 2009).

Wind speed also weakly to moderately inversely correlated with aerosol concentration and mass. This relationship may be driven by the enhanced formation of coarse-mode primary marine aerosol (PMA) at higher wind speeds. Specifically, enhanced PMA concentrations can prevent sulfate particles from activating to cloud droplets and growing through cloud processing. This result is consistent with a modeling 


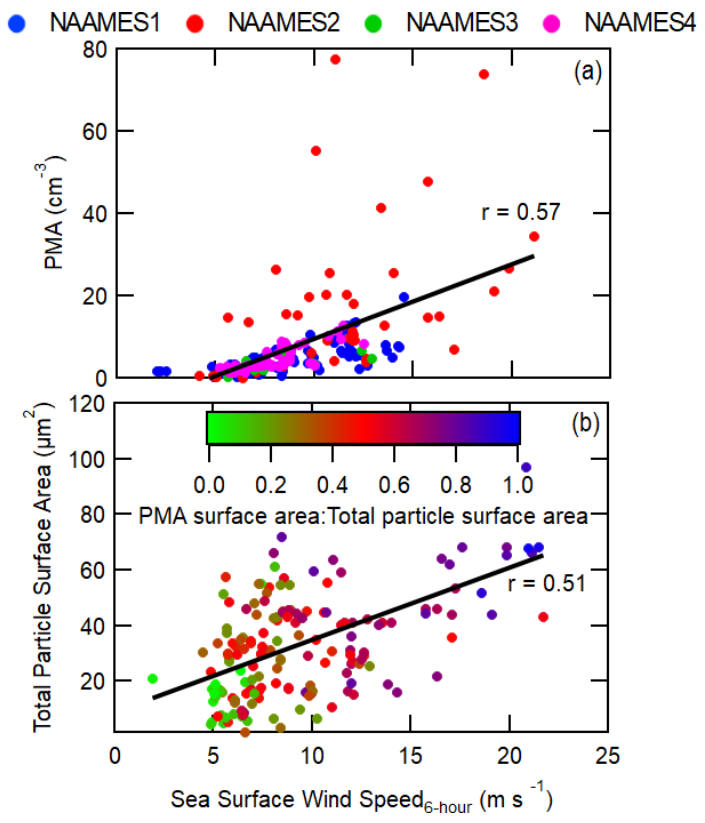

Figure 8. Measurements of (a) the PMA-mode number concentration and (b) total particle surface area compared to $6 \mathrm{~h}$ FLEXPART residence-time-weighted model reanalysis wind speed. Both the total particle surface area and the PMA-mode concentration are derived from the SEMS and APS instruments on the R/V Atlantis. Pearson's coefficients $(r)$ are included for each plot along with bestfit lines shown as black lines.

study indicating that the enhanced rate of water vapor condensation onto PMA resulted in decreased cloud supersaturations (Fossum et al., 2020). The concentration of particles greater than $100 \mathrm{~nm}$ in diameter negatively correlated with wind speed $(r=-0.42)$, consistent with this hypothesis; however, sulfate $(r=-0.56)$ and organic $(r=-0.37)$ aerosol mass are also negatively correlated with surface wind speed. We attribute this to the condensation of sulfate and VOCs onto PMA. While PMA accounts for a low fraction of the particle number, it is of larger size compared to most particles and shown to account for $41 \pm 23 \%$ of the total particle surface area. Large PMA particles have short lifetimes and deposit quickly relative to submicron particles (Pryor and Barthelmie, 2000). This is supported by the moderate correlation between wind speed and PMA concentrations at $0 \mathrm{~h}$ trajectories $(r=0.59)$, which decreased for longer trajectory lengths. Condensed sulfate and organics on PMA in the MBL would quickly be removed from the atmosphere. In addition, the AMS likely missed most secondary aerosol mass that condensed onto PMA because of its low efficiency for measuring refractory components.

We find that air mass residence time is important for relating aerosol organics to ocean chlorophyll $a$, net primary production, and downward shortwave forcing, with moderate correlations observed for the longer simulation ages. Similarly, sulfate aerosol showed moderate correlations with downward shortwave forcing and was anticorrelated with wind speed. Atmospheric DMS and PMA concentrations showed better correlations with shorter back-trajectory lengths, reflecting their origin as primary emissions. In sum, this work demonstrates the need to account for air mass history when apportioning marine aerosol sources. While this study seeks to understand linkages between the ocean and atmosphere, we have deliberately excluded the influence of most continental transport to the marine atmosphere. Future studies are needed to (1) understand how differences in subtropical and subarctic phytoplankton speciation may influence aerosol concentrations (Bolaños et al., 2020) and (2) quantify the contribution of transported aerosols to the marine $\mathrm{CCN}$ budget and how those may impact (or even dominate) the relationships we have identified in the remote North Atlantic.

Data availability. The NAAMES dataset is archived at the NASA Atmospheric Science Data Center (ASDC; https://doi.org/10.5067/Suborbital/NAAMES/DATA001,

NAAMES Science Team, 2018) and the SeaWiFS Bio-Optical Archive and Storage System (SeaBASS; https://doi.org/10.5067/SeaBASS/NAAMES/DATA001,

Werdell and Bailey, 2002). Scripps measurements are available at https://doi.org/10.6075/J04T6GJ6 (Russell et al., 2018). The GlobColour data (2020) (http://globcolour.info) used in this study have been developed, validated, and distributed by ACRI-ST, France. GDAS data (2020) are available at ftp://arlftp.arlhq.noaa.gov/pub/archives/gdas1/. Modeled net primary production data (2020) are available at http://sites.science.oregonstate.edu/ocean.productivity/custom.php.

Supplement. The supplement related to this article is available online at: https://doi.org/10.5194/acp-21-831-2021-supplement.

Author contributions. KJS and RHM were responsible for the conceptualization, methodology, and writing of the original draft. KJS and $\mathrm{BZ}$ designed the software. KJS performed the formal analysis and visualization. RHM, MHB, and LMR were responsible for supervision, project administration, and funding acquisition. GS, CLC, SLL, PKQ, TSB, JP, TGB, ESS, and MJB curated the data. All authors participated in writing, review, and editing.

Competing interests. The authors declare that they have no conflict of interest.

Special issue statement. This article is part of the special issue "Marine aerosols, trace gases, and clouds over the North Atlantic (ACP/AMT inter-journal SI)". It is not associated with a conference. 
Acknowledgements. We thank the dedicated crew of the R/V Atlantis. Kevin J. Sanchez was funded by the NASA Postdoctoral Program. The authors also would like to acknowledge Raghu Betha, Derek Price, Derek Coffman, and Lucia Upchurch for collecting and reducing data. We thank Emmanuel Boss for his input on the paper. We thank Nils Haentjens for processing the in-line measurements. This is PMEL contribution number 5111. Bo Zhang and Hongyu Liu acknowledge funding support from the NAAMES mission.

Financial support. This research has been supported by the National Aeronautics and Space Administration, Langley Research Center (grant nos. NNX15AE66G, NNX15AF30G, and NNX15AF31G), and the National Science Foundation, Division of Ocean Sciences (grant no. NSFOCE-1537943).

Review statement. This paper was edited by Radovan Krejci and reviewed by two anonymous referees.

\section{References}

Altieri, K. E., Fawcett, S. E., Peters, A. J., Sigman, D. M., and Hastings, M. G.: Marine biogenic source of atmospheric organic nitrogen in the subtropical North Atlantic, P. Natl. Acad. Sci. USA, 113, 925-930, https://doi.org/10.1073/pnas.1516847113, 2016.

Andreae, M. O. and Crutzen, P. J.: Atmospheric aerosols: Biogeochemical sources and role in atmospheric chemistry, Science, 276, 1052-1058, https://doi.org/10.1126/science.276.5315.1052, 1997.

Andronache, C.: Precipitation removal of ultrafine aerosol particles from the atmospheric boundary layer, J. Geophys. Res.-Atmos., 109, 1-10, https://doi.org/10.1029/2003JD004050, 2004.

Arnold, S. R., Spracklen, D. V., Williams, J., Yassaa, N., Sciare, J., Bonsang, B., Gros, V., Peeken, I., Lewis, A. C., Alvain, S., and Moulin, C.: Evaluation of the global oceanic isoprene source and its impacts on marine organic carbon aerosol, Atmos. Chem. Phys., 9, 1253-1262, https://doi.org/10.5194/acp-9-1253-2009, 2009.

Arnold, S. R., Spracklen, D. V., Gebhardt, S., Custer, T., Williams, J., Peeken, I., and Alvain, S.: Relationships between atmospheric organic compounds and air-mass exposure to marine biology, Environ. Chem., 7, 232-241, https://doi.org/10.1071/EN09144, 2010.

Atkinson, R. and Arey, J.: Gas-phase tropospheric chemistry of biogenic volatile organic compounds: A review, Atmos. Environ., 37, 197-219, https://doi.org/10.1016/S1352-2310(03)00391-1, 2003.

Ayers, G. P. and Gras, J. L.: Seasonal relationship between cloud condensation nuclei and aerosol methanesulfonate in marine air, Nature, 353, 834-835, https://doi.org/10.1038/353834a0, 1991.

Ayers, G. P., Cainey, J. M., Gillett, R. W., and Ivey, J. P.: Atmospheric sulphur and cloud condensation nuclei in marine air in the Southern Hemisphere, Philos. T. R. Soc. B, 352, 203-211, https://doi.org/10.1098/rstb.1997.0015, 1997.

Bates, T. S., Kapustin, V. N., Quinn, P. K., Covert, D. S., Coffman, D. J., Mari, C., Durkee, P. A., De Bruyn, W. J., and Saltzman, E.
S.: Processes controlling the distribution of aerosol particles in the lower marine boundary layer during the First Aerosol Characterization Experiment (ACE 1), J. Geophys. Res., 103, 1636916383, https://doi.org/10.1029/97jd03720, 1998a.

Bates, T. S., Carney, J. M., DeBruyn, W. J., and Saltzman, F. S.: Shipboard measurements of dimethyl sulfide and $\mathrm{SO}_{2}$ southwest of Tasmania during the First Aerosol Characterization Experiment (ACE 1), J. Geophys. Res.-Atmos., 103, 16703-16711, https://doi.org/10.1029/98JD00971, 1998b.

Bates, T. S., Quinn, P. K., Frossard, A. A., Russell, L. M., Hakala, J., Petaja, T., Kulmala, M., Covert, D. S., Cappa, C. D., Li, S. M., Hayden, K. L., Nuaaman, I., McLaren, R., Massoli, P., Canagaratna, M. R., Onasch, T. B., Sueper, D., Worsnop, D. R., and Keene, W. C.: Measurements of ocean derived aerosol off the coast of California, J. Geophys. Res., 117, D00V15, https://doi.org/10.1029/2012jd017588, 2012.

Beck, H. E., Pan, M., Roy, T., Weedon, G. P., Pappenberger, F., van Dijk, A. I. J. M., Huffman, G. J., Adler, R. F., and Wood, E. F.: Daily evaluation of 26 precipitation datasets using Stage-IV gauge-radar data for the CONUS, Hydrol. Earth Syst. Sci., 23, 207-224, https://doi.org/10.5194/hess-23-207-2019, 2019.

Behrenfeld, M. J.: Abandoning sverdrup's critical depth hypothesis on phytoplankton blooms, Ecology, 91, 977-989, https://doi.org/10.1890/09-1207.1, 2010.

Behrenfeld, M. J. and Boss, E. S.: Student's tutorial on bloom hypotheses in the context of phytoplankton annual cycles, Glob. Change Biol., 24, 55-77, https://doi.org/10.1111/gcb.13858, 2018.

Behrenfeld, M. J., O’Malley, R. T., Boss, E. S., Westberry, T. K., Graff, J. R., Halsey, K. H., Milligan, A. J., Siegel, D. A., and Brown, M. B.: Revaluating ocean warming impacts on global phytoplankton, Nat. Clim. Chang., 6, 323-330, https://doi.org/10.1038/nclimate2838, 2016.

Behrenfeld, M. J., Moore, R. H., Hostetler, C. A., Graff, J., Gaube, P., Russell, L. M., Chen, G., Doney, S. C., Giovannoni, S., Liu, H., Proctor, C., Bolaños, L. M., Baetge, N., Davie-Martin, C., Westberry, T. K., Bates, T. S., Bell, T. G., Bidle, K. D., Boss, E. S., Brooks, S. D., Cairns, B., Carlson, C., Halsey, K., Harvey, E. L., Hu, C., Karp-Boss, L., Kleb, M., Menden-Deuer, S., Morison, F., Quinn, P. K., Scarino, A. J., Anderson, B., Chowdhary, J., Crosbie, E., Ferrare, R., Hair, J. W., Hu, Y., Janz, S., Redemann, J., Saltzman, E., Shook, M., Siegel, D. A., Wisthaler, A., Martin, M. Y., and Ziemba, L.: The North Atlantic Aerosol and Marine Ecosystem Study (NAAMES): Science motive and mission overview, Front. Mar. Sci., 6, 1-25, https://doi.org/10.3389/fmars.2019.00122, 2019.

Bell, T. G., De Bruyn, W., Miller, S. D., Ward, B., Christensen, K. H., and Saltzman, E. S.: Air-sea dimethylsulfide (DMS) gas transfer in the North Atlantic: evidence for limited interfacial gas exchange at high wind speed, Atmos. Chem. Phys., 13, 1107311087, https://doi.org/10.5194/acp-13-11073-2013, 2013.

Bell, T. G., De Bruyn, W., Marandino, C. A., Miller, S. D., Law, C. S., Smith, M. J., and Saltzman, E. S.: Dimethylsulfide gas transfer coefficients from algal blooms in the Southern Ocean, Atmos. Chem. Phys., 15, 1783-1794, https://doi.org/10.5194/acp15-1783-2015, 2015.

Bell, T. G., Porter, J. G., Wang, W., Lawler, M., Boss, E., Behrenfeld, M., and Saltzman, E. S.: Seawater DMS variability during the North Atlantic Aerosol and Ma- 
rine Ecosystem Study (NAAMES), Front. Mar. Sci., https://doi.org/10.3389/fmars.2020.596763, accepted, 2020.

Betha, R., Russell, L. M., Sanchez, K. J., Liu, J., Price, D. J., Lamjiri, M. A., Chen, C.-L., Kuang, X. M., da Rocha, G. O., Paulson, S. E., Miller, J. W., and Cocker, D. R.: Lower $\mathrm{NO}_{x}$ but higher particle and black carbon emissions from renewable diesel compared to ultra low sulfur diesel in at-sea operations of a research vessel, Aerosol Sci. Tech., 51, 123-134, https://doi.org/10.1080/02786826.2016.1238034, 2017.

Bolaños, L. M., Karp-Boss, L., Choi, C. J., Worden, A. Z., Graff, J. R., Haëntjens, N., Chase, A. P., Della Penna, A., Gaube, P., Morison, F., Menden-Deuer, S., Westberry, T. K., O’Malley, R. T., Boss, E., Behrenfeld, M. J., and Giovannoni, S. J.: Small phytoplankton dominate western North Atlantic biomass, ISME J., 14, 1663-1674, https://doi.org/10.1038/s41396-020-0636-0, 2020.

Booge, D., Marandino, C. A., Schlundt, C., Palmer, P. I., Schlundt, M., Atlas, E. L., Bracher, A., Saltzman, E. S., and Wallace, D. W. R.: Can simple models predict large-scale surface ocean isoprene concentrations?, Atmos. Chem. Phys., 16, 11807-11821, https://doi.org/10.5194/acp-16-11807-2016, 2016.

Boss, E. and Behrenfeld, M.: In situ evaluation of the initiation of the North Atlantic phytoplankton bloom, Geophys. Res. Lett., 37, 1-5, https://doi.org/10.1029/2010GL044174, 2010.

Boss, E., Picheral, M., Leeuw, T., Chase, A., Karsenti, E., Gorsky, G., Taylor, L., Slade, W., Ras, J., and Claustre, H.: The characteristics of particulate absorption, scattering and attenuation coefficients in the surface ocean; Contribution of the Tara Oceans expedition, Methods Oceanogr., 7, 52-62, https://doi.org/10.1016/j.mio.2013.11.002, 2013.

Bouillon, R.-C. and Miller, W. L.: Determination of apparent quantum yield spectra of DMS photo-degradation in an in situ ironinduced Northeast Pacific Ocean bloom, Geophys. Res. Lett., 31, L06310, https://doi.org/10.1029/2004g1019536, 2004.

Brimblecombe, P. and Shooter, D.: Photo-oxidation of dimethylsulphide in aqueous solution, Mar. Chem., 19, 343-353, https://doi.org/10.1016/0304-4203(86)90055-1, 1986.

Brooks, S. D. and Thornton, D. C. O.: Marine Aerosols and Clouds, Annu. Rev. Mar. Sci., 10, 289-313, https://doi.org/10.1146/annurev-marine-121916-063148, 2018.

Brüggemann, M., Hayeck, N., and George, C.: Interfacial photochemistry at the ocean surface is a global source of organic vapors and aerosols, Nat. Commun., 9, 1-8, https://doi.org/10.1038/s41467-018-04528-7, 2018.

Cainey, J. M. and Harvey, M.: Dimethylsulfide, a limited contributor to new particle formation in the clean marine boundary layer, Geophys. Res. Lett., 29, 32-1-32-4, https://doi.org/10.1029/2001GL014439, 2002.

Ceburnis, D., Garbaras, A., Szidat, S., Rinaldi, M., Fahrni, S., Perron, N., Wacker, L., Leinert, S., Remeikis, V., Facchini, M. C., Prevot, A. S. H., Jennings, S. G., Ramonet, M., and O'Dowd, C. D.: Quantification of the carbonaceous matter origin in submicron marine aerosol by ${ }^{13} \mathrm{C}$ and ${ }^{14} \mathrm{C}$ isotope analysis, Atmos. Chem. Phys., 11, 8593-8606, https://doi.org/10.5194/acp11-8593-2011, 2011.

Charlson, R. J., Lovelock, J. E., Andreae, M. O., and Warren, S. G.: Oceanic phytoplankton, atmospheric sulfur, cloud albedo and climate, Nature, 326, 655-661, https://doi.org/10.1038/326655a0, 1987.
Chen, T. and Jang, M.: Secondary organic aerosol formation from photooxidation of a mixture of dimethyl sulfide and isoprene, Atmos. Environ., 46, 271-278, https://doi.org/10.1016/j.atmosenv.2011.09.082, 2012.

Clarke, A. D.: Atmospheric nuclei in the pacific midtroposphere their nature, concentration, and evolution, J. Geophys. Res., 98, 20633-20647, https://doi.org/10.1029/93jd00797, 1993.

Clarke, A. D., Kapustin, V. N., Eisele, F. L., Weber, R. J., and McMurry, P. H.: Particle production near marine clouds: Sulfuric acid and predictions from classical binary nucleation, Geophys. Res. Lett., 26, 2425-2428, https://doi.org/10.1029/1999g1900438, 1999.

Clarke, A. D., Freitag, S., Simpson, R. M. C., Hudson, J. G., Howell, S. G., Brekhovskikh, V. L., Campos, T., Kapustin, V. N., and Zhou, J.: Free troposphere as a major source of $\mathrm{CCN}$ for the equatorial pacific boundary layer: long-range transport and teleconnections, Atmos. Chem. Phys., 13, 7511-7529, https://doi.org/10.5194/acp-13-7511-2013, 2013.

Coggon, M. M., Sorooshian, A., Wang, Z., Metcalf, A. R., Frossard, A. A., Lin, J. J., Craven, J. S., Nenes, A., Jonsson, H. H., Russell, L. M., Flagan, R. C., and Seinfeld, J. H.: Ship impacts on the marine atmosphere: insights into the contribution of shipping emissions to the properties of marine aerosol and clouds, Atmos. Chem. Phys., 12, 8439-8458, https://doi.org/10.5194/acp12-8439-2012, 2012.

Covert, D. S., Kapustin, V. N., Quinn, P. K., and Bates, T. S.: New particle formation in the marine boundary-layer, J. Geophys. Res., 97, 20581-20589, https://doi.org/10.1029/92jd02074, 1992.

Croft, B., Lohmann, U., Martin, R. V., Stier, P., Wurzler, S., Feichter, J., Hoose, C., Heikkilä, U., van Donkelaar, A., and Ferrachat, S.: Influences of in-cloud aerosol scavenging parameterizations on aerosol concentrations and wet deposition in ECHAM5-HAM, Atmos. Chem. Phys., 10, 1511-1543, https://doi.org/10.5194/acp-10-1511-2010, 2010.

Cui, T., Green, H. S., Selleck, P. W., Zhang, Z., O’Brien, R. E., Gold, A., Keywood, M., Kroll, J. H., and Surratt, J. D.: Chemical Characterization of Isoprene- and Monoterpene-Derived Secondary Organic Aerosol Tracers in Remote Marine Aerosols over a Quarter Century, ACS Earth Sp. Chem., 3, 935-946, https://doi.org/10.1021/acsearthspacechem.9b00061, 2019.

Dani, K. G. S. and Loreto, F.: Trade-Off Between Dimethyl Sulfide and Isoprene Emissions from Marine Phytoplankton, Trends Plant Sci., 22, 361-372, https://doi.org/10.1016/j.tplants.2017.01.006, 2017.

DeCarlo, P. F., Kimmel, J. R., Trimborn, A., Northway, M. J., Jayne, J. T., Aiken, A. C., Gonin, M., Fuhrer, K., Horvath, T., Docherty, K. S., Worsnop, D. R., and Jimenez, J. L.: Field-deployable, high-resolution, time-of-flight aerosol mass spectrometer, Anal. Chem., 78, 8281-8289, https://doi.org/10.1021/ac061249n, 2006.

de Leeuw, G., Andreas, E. L., Anguelova, M. D., Fairall, C. W., Lewis, E. R., O'Dowd, C., Schulz, M., and Schwartz, S. E.: Production flux of sea spray aerosol, Rev. Geophys., 49, RG2001, https://doi.org/10.1029/2010rg000349, 2011.

Devore, J. L. and Berk, K. N.: Modern Mathematical Statistics with Application, 2nd Edn., Springer Science+Business Media, New York, 2012. 
Dzepina, K., Mazzoleni, C., Fialho, P., China, S., Zhang, B., Owen, R. C., Helmig, D., Hueber, J., Kumar, S., Perlinger, J. A., Kramer, L. J., Dziobak, M. P., Ampadu, M. T., Olsen, S., Wuebbles, D. J., and Mazzoleni, L. R.: Molecular characterization of free tropospheric aerosol collected at the Pico Mountain Observatory: a case study with a long-range transported biomass burning plume, Atmos. Chem. Phys., 15, 5047-5068, https://doi.org/10.5194/acp-15-5047-2015, 2015.

Ehn, M., Thornton, J. A., Kleist, E., Sipilä, M., Junninen, H., Pullinen, I., Springer, M., Rubach, F., Tillmann, R., Lee, B., Lopez-Hilfiker, F., Andres, S., Acir, I. H., Rissanen, M., Jokinen, T., Schobesberger, S., Kangasluoma, J., Kontkanen, J., Nieminen, T., Kurtén, T., Nielsen, L. B., Jørgensen, S., Kjaergaard, H. G., Canagaratna, M., Maso, M. D., Berndt, T., Petäjä, T., Wahner, A., Kerminen, V. M., Kulmala, M., Worsnop, D. R., Wildt, J., and Mentel, T. F.: A large source of lowvolatility secondary organic aerosol, Nature, 506, 476-479, https://doi.org/10.1038/nature13032, 2014.

Facchini, M. C., Decesari, S., Rinaldi, M., Carbone, C., Finessi, E., Mircea, M., Fuzzi, S., Moretti, F., Tagliavini, E., Ceburnis, D., and O'Dowd, C. D.: Important source of marine secondary organic aerosol from biogenic amines, Environ. Sci. Technol., 42, 9116-9121, https://doi.org/10.1021/es8018385, 2008.

Faloona, I., Conley, S. A., Blomquist, B., Clarke, A. D., Kapustin, V., Howell, S., Lenschow, D. H., and Bandy, A. R.: Sulfur dioxide in the tropical marine boundary layer: Dry deposition and heterogeneous oxidation observed during the pacific atmospheric sulfur experiment, J. Atmos. Chem., 63, 13-32, https://doi.org/10.1007/s10874-010-9155-0, 2009.

Fossum, K. N., Ovadnevaite, J., Ceburnis, D., Dall'Osto, M., Marullo, S., Bellacicco, M., Simó, R., Liu, D., Flynn, M., Zuend, A., and O'Dowd, C.: Summertime Primary and Secondary Contributions to Southern Ocean Cloud Condensation Nuclei, Sci. Rep.-UK, 8, 13844, https://doi.org/10.1038/s41598-018-320474, 2018.

Fossum, K. N., Ovadnevaite, J., Ceburnis, D., Preißler, J., Snider, J. R., Huang, R.-J., Zuend, A., and O'Dowd, C.: Sea-spray regulates sulfate cloud droplet activation over oceans, npj Clim. Atmos. Sci., 3, 14, https://doi.org/10.1038/s41612-020-0116-2, 2020.

Frossard, A. A., Russell, L. M., Massoli, P., Bates, T. S., and Quinn, P. K.: Side-by-Side Comparison of Four Techniques Explains the Apparent Differences in the Organic Composition of Generated and Ambient Marine Aerosol Particles, Aerosol Sci. Tech., 48, V-X, https://doi.org/10.1080/02786826.2013.879979, 2014a.

Frossard, A. A., Russell, L. M., Burrows, S. M., Elliott, S. M., Bates, T. S., and Quinn, P. K.: Sources and composition of submicron organic mass in marine aerosol particles, J. Geophys. Res., 119, 12977-13003, https://doi.org/10.1002/2014jd021913, 2014b.

Frossard, A. A., Li, W., Gérard, V., Nozière, B., and Cohen, R. C.: Influence of surfactants on growth of individual aqueous coarse mode aerosol particles, Aerosol Sci. Tech., 52, 459-469, https://doi.org/10.1080/02786826.2018.1424315, 2018.

Gantt, B., Meskhidze, N., and Kamykowski, D.: A new physicallybased quantification of marine isoprene and primary organic aerosol emissions, Atmos. Chem. Phys., 9, 4915-4927, https://doi.org/10.5194/acp-9-4915-2009, 2009.
GDAS data: ftp://arlftp.arlhq.noaa.gov/pub/archives/gdas1/, last access: 2 October 2019.

GlobColour data: http://globcolour.info, last access: 9 April 2020.

Grythe, H., Ström, J., Krejci, R., Quinn, P., and Stohl, A.: A review of sea-spray aerosol source functions using a large global set of sea salt aerosol concentration measurements, Atmos. Chem. Phys., 14, 1277-1297, https://doi.org/10.5194/acp-141277-2014, 2014.

Gunson, J. R., Spall, S. A., Anderson, T. R., Jones, A., Totterdell, I. J., and Woodage, M. J.: Climate sensitivity to ocean dimethylsulphide emissions, Geophys. Res. Lett., 33, 2-5, https://doi.org/10.1029/2005GL024982, 2006.

Hallquist, M., Wenger, J. C., Baltensperger, U., Rudich, Y., Simpson, D., Claeys, M., Dommen, J., Donahue, N. M., George, C., Goldstein, A. H., Hamilton, J. F., Herrmann, H., Hoffmann, T., Iinuma, Y., Jang, M., Jenkin, M. E., Jimenez, J. L., Kiendler-Scharr, A., Maenhaut, W., McFiggans, G., Mentel, Th. F., Monod, A., Prévôt, A. S. H., Seinfeld, J. H., Surratt, J. D., Szmigielski, R., and Wildt, J.: The formation, properties and impact of secondary organic aerosol: current and emerging issues, Atmos. Chem. Phys., 9, 5155-5236, https://doi.org/10.5194/acp9-5155-2009, 2009.

Hasekamp, O. P., Gryspeerdt, E., and Quaas, J.: Analysis of polarimetric satellite measurements suggests stronger cooling due to aerosol-cloud interactions, Nat. Commun., 10, 1-7, https://doi.org/10.1038/s41467-019-13372-2, 2019.

Hoppel, W. A., Frick, G. M., and Larson, R. E.: Effect of nonprecipitating clouds on the aerosol size distribution in the marine boundary layer, Geophys. Res. Lett., 13, 125-128, https://doi.org/10.1029/GL013i002p00125, 1986.

Hu, Q. H., Xie, Z. Q., Wang, X. M., Kang, H., He, Q. F., and Zhang, P.: Secondary organic aerosols over oceans via oxidation of isoprene and monoterpenes from Arctic to Antarctic, Sci. Rep.-UK, 3, 1-7, https://doi.org/10.1038/srep02280, 2013.

Huang, S., Wu, Z., Poulain, L., van Pinxteren, M., Merkel, M., Assmann, D., Herrmann, H., and Wiedensohler, A.: Source apportionment of the organic aerosol over the Atlantic Ocean from $53^{\circ} \mathrm{N}$ to $53^{\circ} \mathrm{S}$ : significant contributions from marine emissions and long-range transport, Atmos. Chem. Phys., 18, 1804318062, https://doi.org/10.5194/acp-18-18043-2018, 2018 a.

Huang, S., Wu, Z., Poulain, L., van Pinxteren, M., Merkel, M., Assmann, D., Herrmann, H., and Wiedensohler, A.: Source apportionment of the organic aerosol over the Atlantic Ocean from $53^{\circ} \mathrm{N}$ to $53^{\circ} \mathrm{S}$ : significant contributions from marine emissions and long-range transport, Atmos. Chem. Phys., 18, 1804318062, https://doi.org/10.5194/acp-18-18043-2018, 2018 b.

Hudson, J. G., Noble, S., and Tabor, S.: Journal of Geophysical Research?: Atmospheres Cloud supersaturations from CCN spectra Hoppel minima, 120, 3436-3452, https://doi.org/10.1002/2014JD022669, 2015.

Humphries, R. S., Schofield, R., Keywood, M. D., Ward, J., Pierce, J. R., Gionfriddo, C. M., Tate, M. T., Krabbenhoft, D. P., Galbally, I. E., Molloy, S. B., Klekociuk, A. R., Johnston, P. V., Kreher, K., Thomas, A. J., Robinson, A. D., Harris, N. R. P., Johnson, R., and Wilson, S. R.: Boundary layer new particle formation over East Antarctic sea ice - possible Hg-driven nucleation?, Atmos. Chem. Phys., 15, 13339-13364, https://doi.org/10.5194/acp-15-13339-2015, 2015. 
Jacob, D. J.: Heterogeneous chemistry and tropospheric ozone, Atmos. Environ., 34, 2131-2159, https://doi.org/10.1016/S13522310(99)00462-8, 2000.

Keller, M. D.: Dimethyl sulfide production and marine phytoplankton: the importance of species composition and cell size, Biol. Oceanogr., 6, 375-382, 1988.

Kloster, S., Feichter, J., Maier-Reimer, E., Six, K. D., Stier, P., and Wetzel, P.: DMS cycle in the marine ocean-atmosphere system - a global model study, Biogeosciences, 3, 29-51, https://doi.org/10.5194/bg-3-29-2006, 2006.

Korhonen, H., Carslaw, K. S., Spracklen, D. V., Mann, G. W., and Woodhouse, M. T.: Influence of oceanic dimethyl sulfide emissions on cloud condensation nuclei concentrations and seasonality over the remote Southern Hemisphere oceans: A global model study, J. Geophys. Res., 113, D15204, https://doi.org/10.1029/2007jd009718, 2008.

Leahy, L. V, Wood, R., Charlson, R. J., Hostetler, C. A., Rogers, R. R., Vaughan, M. A., and Winker, D. M.: On the nature and extent of optically thin marine low clouds, J. Geophys. Res.-Atmos., 117, D22201, https://doi.org/10.1029/2012jd017929, 2012.

Lee, A., Goldstein, A. H., Kroll, J. H., Ng, N. L., Varutbangkul, V., Flagan, R. C., and Seinfeld, J. H.: Gas-phase products and secondary aerosol yields from the photooxidation of 16 different terpenes, J. Geophys. Res.-Atmos., 111, 1-25, https://doi.org/10.1029/2006JD007050, 2006.

Li, J., Jian, B., Huang, J., Hu, Y., Zhao, C., Kawamoto, K., Liao, $\mathrm{S}$., and $\mathrm{Wu}, \mathrm{M}$.: Long-term variation of cloud droplet number concentrations from space-based Lidar, Remote Sens. Environ., 213, 144-161, https://doi.org/10.1016/J.RSE.2018.05.011, 2018.

Liakakou, E., Vrekoussis, M., Bonsang, B., Donousis, C., Kanakidou, M., and Mihalopoulos, N.: Isoprene above the Eastern Mediterranean: Seasonal variation and contribution to the oxidation capacity of the atmosphere, Atmos. Environ., 41, 10021010, https://doi.org/10.1016/j.atmosenv.2006.09.034, 2007.

Lyngsgaard, M. M., Markager, S., Richardson, K., Møller, E. F., and Jakobsen, H. H.: How Well Does Chlorophyll Explain the Seasonal Variation in Phytoplankton Activity?, Estuar. Coasts, 40, 1263-1275, https://doi.org/10.1007/s12237-017-0215-4, 2017.

Mansour, K., Decesari, S., Facchini, M. C., Belosi, F., Paglione, M., Sandrini, S., Bellacicco, M., Marullo, S., Santoleri, R., Ovadnevaite, J., Ceburnis, D., O’Dowd, C., Roberts, G., Sanchez, K., and Rinaldi, M.: Linking Marine Biological Activity to Aerosol Chemical Composition and Cloud-Relevant Properties over the North Atlantic Ocean, J. Geophys. Res.-Atmos., 125, e2019JD032246, https://doi.org/10.1029/2019jd032246, 2020.

Maritorena, S. and Siegel, D. A.: Consistent merging of satellite ocean color data sets using a biooptical model, Remote Sens. Environ., 94, 429-440, https://doi.org/10.1016/j.rse.2004.08.014, 2005.

Maritorena, S., d'Andon, O. H. F., Mangin, A., and Siegel, D. A.: Merged satellite ocean color data products using a bio-optical model: Characteristics, benefits and issues, Remote Sens. Environ., 114, 1791-1804, https://doi.org/10.1016/j.rse.2010.04.002, 2010.

McCoy, D. T., Burrows, S. M., Wood, R., Grosvenor, D. P., Elliott, S. M., Ma, P.-L. L., Rasch, P. J., and Hartmann, D. L.: Natural aerosols explain seasonal and spatial patterns of Southern Ocean cloud albedo, Sci. Adv., 1, e1500157-e1500157, https://doi.org/10.1126/sciadv.1500157, 2015.
Meskhidze, N. and Nenes, A.: Phytoplankton and Cloudiness in the Southern Ocean, Science, 314, 1419-1423, https://doi.org/10.1126/science.1131779, 2006.

Meskhidze, N. and Nenes, A.: Effects of Ocean Ecosystem on Marine Aerosol-Cloud Interaction, Adv. Meteorol., 2010, 1-13, https://doi.org/10.1155/2010/239808, 2010.

Modeled net primary production data: http://sites.science. oregonstate.edu/ocean.productivity/custom.php, last access: 9 April 2020.

Modini, R. L., Frossard, A. A., Ahlm, L., Russell, L. M., Corrigan, C. E., Roberts, G. C., Hawkins, L. N., Schroder, J. C., Bertram, A. K., Zhao, R., Lee, A. K. Y., Abbatt, J. P. D., Lin, J., Nenes, A., Wang, Z., Wonaschuetz, A., Sorooshian, A., Noone, K. J., Jonsson, H., Seinfeld, J. H., Toom-Sauntry, D., Macdonald, A. M., and Leaitch, W. R.: Primary marine aerosol-cloud interactions off the coast of California, J. Geophys. Res., 120, 4282-4303, https://doi.org/10.1002/2014jd022963, 2015.

Morel, A., Huot, Y., Gentili, B., Werdell, P. J., Hooker, S. B., and Franz, B. A.: Examining the consistency of products derived from various ocean color sensors in open ocean (Case 1) waters in the perspective of a multi-sensor approach, Remote Sens. Environ., 111, 69-88, https://doi.org/10.1016/j.rse.2007.03.012, 2007.

Mungall, E. L., Croft, B., Lizotte, M., Thomas, J. L., Murphy, J. G., Levasseur, M., Martin, R. V., Wentzell, J. J. B., Liggio, J., and Abbatt, J. P. D.: Dimethyl sulfide in the summertime Arctic atmosphere: measurements and source sensitivity simulations, Atmos. Chem. Phys., 16, 6665-6680, https://doi.org/10.5194/acp16-6665-2016, 2016.

Murphy, D. M., Anderson, J. R., Quinn, P. K., McInnes, L. M., Brechtel, F. J., Kreidenweis, S. M., Middlebrook, A. M., Pósfai, M., Thomson, D. S., Buseck, P. R., Posfai, M., Thomson, D. S., and Buseck, P. R.: Influence of sea-salt on aerosol radiative properties in the Southern Ocean marine boundary layer, Nature, 392, 62-65, https://doi.org/10.1038/32138, 1998.

Myriokefalitakis, S., Vignati, E., Tsigaridis, K., Papadimas, C., Sciare, J., Mihalopoulos, N., Facchini, M. C., Rinaldi, M., Dentener, F. J., Ceburnis, D., Hatzianastasiou, N., O’Dowd, C. D., van Weele, M., and Kanakidou, M.: Global Modeling of the Oceanic Source of Organic Aerosols, Adv. Meteorol., 2010, 116, https://doi.org/10.1155/2010/939171, 2010.

NAAMES Science Team: North Atlantic Aerosols and Marine Ecosystems Study, NASA Langley Atmospheric Science Data Center DAAC, https://doi.org/10.5067/SUBORBITAL/NAAMES/DATA001 (last access: 9 April 2020), 2018.

Nelson, N. B. and Siegel, D. A.: The Global Distribution and Dynamics of Chromophoric Dissolved Organic Matter, Annu. Rev. Mar. Sci., 5, 447-476, https://doi.org/10.1146/annurev-marine120710-100751, 2013.

O'Connor, T. C., Jennings, S. G., and O'Dowd, C. D.: Highlights of fifty years of atmospheric aerosol research at Mace Head, Atmos. Res., 90, 338-355, https://doi.org/10.1016/j.atmosres.2008.08.014, 2008.

O’Dowd, C. D., Hämeri, K., Mäkelä, J. M., Pirjola, L., Kulmala, M., Jennings, S. G., Berresheim, H., Hansson, H. C., De Leeuw, G., Kunz, G. J., Allen, A. G., Hewitt, C. N., Jackson, A., Viisanen, Y., and Hoffmann, T.: A dedicated study of New Particle Formation and Fate in the Coastal Envi- 
ronment (PARFORCE): Overview of objectives and achievements, J. Geophys. Res.-Atmos., 107, PAR 1-1-PAR 1-16, https://doi.org/10.1029/2001JD000555, 2002.

O'Dowd, C. D., Smith, M. H., Consterdine, I. E., and Lowe, J. A.: Marine aerosol, sea-salt, and the marine sulphur cycle: A short review, Atmos. Environ., 31, 73-80, 1997.

Ovadnevaite, J., Ceburnis, D., Leinert, S., Dall'Osto, M., Canagaratna, M., O’Doherty, S., Berresheim, H., and O'Dowd, C.: Submicron NE Atlantic marine aerosol chemical composition and abundance: Seasonal trends and air mass categorization, J. Geophys. Res., 119, 11850-11863, https://doi.org/10.1002/2013jd021330, 2014.

Ovadnevaite, J., Zuend, A., Laaksonen, A., Sanchez, K. J., Roberts, G., Ceburnis, D., Decesari, S., Rinaldi, M., Hodas, N., Facchini, M. C., Seinfeld, J. H., and O'Dowd, C.: Surface tension prevails over solute effect in organic-influenced cloud droplet activation, Nature, 546, 637-641, https://doi.org/10.1038/nature22806, 2017.

Owen, R. C. and Honrath, R. E.: Technical note: a new method for the Lagrangian tracking of pollution plumes from source to receptor using gridded model output, Atmos. Chem. Phys., 9, 2577-2595, https://doi.org/10.5194/acp-9-2577-2009, 2009.

Pandis, S. N., Wexler, A. S., and Seinfeld, J. H.: Dynamics of tropospheric aerosols, J. Phys. Chem., 99, 9646-9659, https://doi.org/10.1021/j100024a003, 1995.

Park, K.-T., Jang, S., Lee, K., Yoon, Y. J., Kim, M.-S., Park, K., Cho, H.-J., Kang, J.-H., Udisti, R., Lee, B.-Y., and Shin, K.-H.: Observational evidence for the formation of DMS-derived aerosols during Arctic phytoplankton blooms, Atmos. Chem. Phys., 17, 9665-9675, https://doi.org/10.5194/acp-17-9665-2017, 2017.

Park, K. T., Lee, K., Kim, T. W., Yoon, Y. J., Jang, E. H., Jang, S., Lee, B. Y., and Hermansen, O.: Atmospheric DMS in the Arctic Ocean and Its Relation to Phytoplankton Biomass, Global Biogeochem. Cy., 32, 351-359, https://doi.org/10.1002/2017GB005805, 2018.

Pastor, M. V., Palter, J. B., Pelegrí, J. L., and Dunne, J. P.: Physical drivers of interannual chlorophyll variability in the eastern subtropical North Atlantic, J. Geophys. Res.-Ocean., 118, 38713886, https://doi.org/10.1002/jgrc.20254, 2013.

Petroff, A. and Zhang, L.: Development and validation of a size-resolved particle dry deposition scheme for application in aerosol transport models, Geosci. Model Dev., 3, 753-769, https://doi.org/10.5194/gmd-3-753-2010, 2010.

Pierce, J. R. and Adams, P. J.: Global evaluation of CCN formation by direct emission of sea salt and growth of ultrafine sea salt, J. Geophys. Res., 111, D06203, https://doi.org/10.1029/2005jd006186, 2006.

Pirjola, L., Lehtinen, K. E. J., Hansson, H. C., and Kulmala, M.: How important is nucleation in regional/global modelling?, Geophys. Res. Lett., 31, L12109, https://doi.org/10.1029/2004g1019525, 2004.

Platnick, S. and Twomey, S.: Determining the Susceptibility of Cloud Albedo to Changes in Droplet Concentration with the Advanced Very High Resolution Radiometer, J. Appl. Meteorol., 33, 334-347, https://doi.org/10.1175/15200450(1994)033<0334:dtsoca>2.0.co;2, 1994.

Pruppacher, H. R. and Klett, J. D.: Microphysics of Clouds and Precipitation, Kluwer Academic Publishers, Dordrecht, 1997.
Pryor, S. C. and Barthelmie, R. J.: Particle dry deposition to water surfaces: Processes and consequences, Seas Millenn. - Environ. Eval., 3, 197-209, 2000.

Quinn, P. K. and Bates, T. S.: The case against climate regulation via oceanic phytoplankton sulphur emissions, Nature, 480, 5156, https://doi.org/10.1038/nature10580, 2011.

Quinn, P. K., Bates, T. S., Miller, T. L., Coffman, D. J., Johnson, J. E., Harris, J. M., Ogren, J. A., Forbes, G., Anderson, T. L., Covert, D. S., and Rood, M. J.: Surface submicron aerosol chemical composition: What fraction is not sulfate?, J. Geophys. Res., 105, 6785-6805, https://doi.org/10.1029/1999jd901034, 2000.

Quinn, P. K., Bates, T. S., Schulz, K. S., Coffman, D. J., Frossard, A. A., Russell, L. M., Keene, W. C., and Kieber, D. J.: Contribution of sea surface carbon pool to organic matter enrichment in sea spray aerosol, Nat. Geosci., 7, 228-232, https://doi.org/10.1038/ngeo2092, 2014.

Quinn, P. K., Coffman, D. J., Johnson, J. E., Upchurch, L. M., and Bates, T. S.: Small fraction of marine cloud condensation nuclei made up of sea spray aerosol, Nat. Geosci., 10, 674-679, https://doi.org/10.1038/ngeo3003, 2017.

Quinn, P. K., Bates, T. S., Coffman, D. J., Upchurch, L., Johnson, J. E., Moore, R., Ziemba, L., Bell, T. G., Saltzman, E. S., Graff, J., and Behrenfeld, M. J.: Seasonal Variations in Western North Atlantic Remote Marine Aerosol Properties, J. Geophys. Res.-Atmos., 124, 14240-14261, https://doi.org/10.1029/2019JD031740, 2019.

Raes, F., VanDingenen, R., Cuevas, E., VanVelthoven, P. F. J., and Prospero, J. M.: Observations of aerosols in the free troposphere and marine boundary layer of the subtropical Northeast Atlantic: Discussion of processes determining their size distribution, J. Geophys. Res., 102, 21315-21328, https://doi.org/10.1029/97jd01122, 1997.

Reus, M., Strom, J., Curtius, J., Pirjola, L., Vignati, E., Arnold, F., Hansson, H. C., Kulmala, M., Lelieveld, J., and Raes, F.: Aerosol production and growth in the upper free troposphere, J. Geophys. Res., 105, 24751-24762, https://doi.org/10.1029/2000jd900382, 2000.

Rinaldi, M., Decesari, S., Finessi, E., Giulianelli, L., Carbone, C., Fuzzi, S., O'Dowd, C. D., Ceburnis, D., and Facchini, M. C.: Primary and Secondary Organic Marine Aerosol and Oceanic Biological Activity: Recent Results and New Perspectives for Future Studies, Adv. Meteorol., 2010, 1-10, https://doi.org/10.1155/2010/310682, 2010.

Russell, L. M., Lenschow, D. H., Laursen, K. K., Krummel, P. B., Siems, S. T., Bandy, A. R., Thornton, D. C., and Bates, T. S.: Bidirectional mixing in an ACE 1 marine boundary layer overlain by a second turbulent layer, J. Geophys. Res.-Atmos., 103, 16411-16432, https://doi.org/10.1029/97JD03437, 1998.

Russell, L. M., Hawkins, L. N., Frossard, A. A., Quinn, P. K., and Bates, T. S.: Carbohydrate-like composition of submicron atmospheric particles and their production from ocean bubble bursting, P. Natl. Acad. Sci. USA, 107, 6652-6657, https://doi.org/10.1073/pnas.0908905107, 2010.

Russell, L. M., Chen, C. L., Betha, R., Price, D. J., and Lewis, S.: Aerosol Particle Chemical and Physical Measurements on the 2015, 2016, 2017, and 2018 North Atlantic Aerosols and Marine Ecosystems Study (NAAMES) Research Cruises, UC San Diego Library Digital Collections, https://doi.org/10.6075/J04T6GJ6 (last access: 9 April 2020), 2018. 
Saliba, G., Chen, C. L., Lewis, S., Russell, L. M., Rivellini, L. H., Lee, A. K. Y., Quinn, P. K., Bates, T. S., Haëntjens, N., Boss, E. S., Karp-Boss, L., Baetge, N., Carlson, C. A., and Behrenfeld, M. J.: Factors driving the seasonal and hourly variability of sea-spray aerosol number in the North Atlantic, P. Natl. Acad. Sci. USA, 116, 20309-20314, https://doi.org/10.1073/pnas.1907574116, 2019.

Saliba, G., Chen, C.-L., Lewis, S., Russell, L. M., Quinn, P. K., Bates, T. S., Bell, T. G., Lawler, M. J., Saltzman, E. S., Sanchez, K. J., Moore, R., Shook, M., Rivellini, L.-H., Lee, A., Baetge, N., Carlson, C. A., and Behrenfeld, M. J.: Seasonal Differences and Variability of Concentrations, Chemical Composition, and Cloud Condensation Nuclei of Marine Aerosol Over the North Atlantic, J. Geophys. Res.-Atmos., 125, e2020JD033145, https://doi.org/10.1029/2020JD033145, 2020.

Sanchez, K. J., Chen, C. L., Russell, L. M., Betha, R., Liu, J., Price, D. J., Massoli, P., Ziemba, L. D., Crosbie, E. C., Moore, R. H., Müller, M., Schiller, S. A., Wisthaler, A., Lee, A. K. Y., Quinn, P. K., Bates, T. S., Porter, J., Bell, T. G., Saltzman, E. S., Vaillancourt, R. D., and Behrenfeld, M. J.: Substantial Seasonal Contribution of Observed Biogenic Sulfate Particles to Cloud Condensation Nuclei, Sci. Rep.-UK, 8, 3235, https://doi.org/10.1038/s41598-018-21590-9, 2018.

Sanchez, K. J., Roberts, G. C., Saliba, G., Russell, L. M., Twohy, C., Reeves, M. J., Humphries, R. S., Keywood, M. D., Ward, J. P., and McRobert, I. M.: Measurement report: Cloud Processes and the Transport of Biological Emissions Regulate Southern Ocean Particle and Cloud Condensation Nuclei Concentrations, Atmos. Chem. Phys. Discuss., https://doi.org/10.5194/acp-2020-731, in review, 2020.

Sciare, J., Baboukas, E., and Mihalopoulos, N.: Short-term variability of atmospheric DMS and its oxidation products at Amsterdam Island during summer time, J. Atmos. Chem., 39, 281-302, https://doi.org/10.1023/A:1010631305307, 2001.

Seinfeld, J. H. and Pandis, S. N.: Atmospheric Chemistry and Physics: From Air Pollution to Climate Change, Wiley, New York, available at: https://books.google.com/books?id= tZEpAQAAMAAJ (last access: 4 September 2020), 2006.

Shank, L. M., Howell, S., Clarke, A. D., Freitag, S., Brekhovskikh, V., Kapustin, V., McNaughton, C., Campos, T., and Wood, R.: Organic matter and non-refractory aerosol over the remote Southeast Pacific: oceanic and combustion sources, Atmos. Chem. Phys., 12, 557-576, https://doi.org/10.5194/acp-12-5572012, 2012.

Shaw, G. E.: Bio-controlled thermostasis involving the sulfur cycle, Climatic Change, 5, 297-303, https://doi.org/10.1007/bf02423524, 1983.

Shaw, S. L., Chisholm, S. W., and Prinn, R. G.: Isoprene production by Prochlorococcus, a marine cyanobacterium, and other phytoplankton, Mar. Chem., 80, 227-245, https://doi.org/10.1016/s0304-4203(02)00101-9, 2003.

Sievering, H., Boatman, J., Gorman, E., Kim, Y., Anderson, L., Ennis, G., Luria, M., and Pandis, S.: Removal of sulfur from the marine boundary-layer by ozone oxidation in sea-salt aerosols, Nature, 360, 571-573, https://doi.org/10.1038/360571a0, 1992.

Sievering, H., Lerner, B., Slavich, J., Anderson, J., Posfai, M., and Cainey, J.: O-3 oxidation of $\mathrm{SO}_{2}$ in sea-salt aerosol water: Size distribution of non-sea-salt sulfate during the First Aerosol Char- acterization Experiment (ACE 1), J. Geophys. Res., 104, 2170721717, https://doi.org/10.1029/1998jd100086, 1999.

Silsbe, G. M., Behrenfeld, M. J., Halsey, K. H., Milligan, A. J., and Westberry, T. K.: The CAFE model: A net production model for global ocean phytoplankton, Global Biogeochem. Cy., 30, 17561777, https://doi.org/10.1002/2016GB005521, 2016.

Sinha, V., Williams, J., Meyerhöfer, M., Riebesell, U., Paulino, A. I., and Larsen, A.: Air-sea fluxes of methanol, acetone, acetaldehyde, isoprene and DMS from a Norwegian fjord following a phytoplankton bloom in a mesocosm experiment, Atmos. Chem. Phys., 7, 739-755, https://doi.org/10.5194/acp-7739-2007, 2007.

Stevens, B. and Feingold, G.: Untangling aerosol effects on clouds and precipitation in a buffered system, Nature, 461, 607-613, https://doi.org/10.1038/nature08281, 2009.

Stohl, A., Forster, C., Frank, A., Seibert, P., and Wotawa, G.: Technical note: The Lagrangian particle dispersion model FLEXPART version 6.2, Atmos. Chem. Phys., 5, 2461-2474, https://doi.org/10.5194/acp-5-2461-2005, 2005.

Thornton, D. C., Bandy, A. R., Blomquist, B. W., Bradshaw, J. D., and Blake, D. R.: Vertical transport of sulfur dioxide and dimethyl sulfide in deep convection and its role in new particle formation, J. Geophys. Res., 102, 28501-28509, https://doi.org/10.1029/97jd01647, 1997.

Thorpe, S. A.: Bubble clouds and the dynamics of the upper ocean, Q. J. Roy. Meteor. Soc., 118, 1-22, https://doi.org/10.1002/qj.49711850302, 1992.

Toole, D. A., Kieber, D. J., Kiene, R. P., Siegel, D. A., and Nelson, N. B.: Photolysis and the dimethylsulfide (DMS) summer paradox in the Sargasso Sea, Limnol. Oceanogr., 48, 1088-1100, https://doi.org/10.4319/lo.2003.48.3.1088, 2003.

Toole, D. A., Siegel, D. A., and Doney, S. C.: A light-driven, one-dimensional dimethylsulfide biogeochemical cycling model for the Sargasso Sea, J. Geophys. Res.-Biogeo., 113, 1-20, https://doi.org/10.1029/2007JG000426, 2008.

Turner, D. D., Vogelmann, A. M., Austin, R. T., Barnard, J. C., Cady-Pereira, K., Chiu, J. C., Clough, S. A., Flynn, C., Khaiyer, M. M., Liljegren, J., Johnson, K., Lin, B., Long, C., Marshak, A., Matrosov, S. Y., McFarlane, S. A., Miller, M., Min, Q., Minimis, P., O'Hirok, W., Wang, Z., and Wiscombe, W.: Thin Liquid Water Clouds: Their Importance and Our Challenge, B. Am. Meteorol. Soc., 88, 177-190, https://doi.org/10.1175/bams-88-2-177, 2007.

Ueda, S., Miura, K., Kawata, R., Furutani, H., Uematsu, M., Omori, Y., and Tanimoto, H.: Number-size distribution of aerosol particles and new particle formation events in tropical and subtropical Pacific Oceans, Atmos. Environ., 142, 324-339, https://doi.org/10.1016/j.atmosenv.2016.07.055, 2016.

Vallina, S. M., Simó, R., and Gassó, S.: What controls CCN seasonality in the Southern Ocean? A statistical analysis based on satellite-derived chlorophyll and $\mathrm{CCN}$ and model-estimated OH radical and rainfall, Global Biogeochem. Cy., 20, GB1014, https://doi.org/10.1029/2005GB002597, 2006.

Van Pinxteren, M., Barthel, S., Fomba, K. W., Müller, K., Von Tümpling, W., and Herrmann, H.: The influence of environmental drivers on the enrichment of organic carbon in the sea surface microlayer and in submicron aerosol particles - measurements from the Atlantic Ocean, Elementa, 5, 35, https://doi.org/10.1525/elementa.225, 2017. 
Veres, P. R., Andrew Neuman, J., Bertram, T. H., Assaf, E., Wolfe, G. M., Williamson, C. J., Weinzierl, B., Tilmes, S., Thompson, C. R., Thames, A. B., Schroder, J. C., Saiz-Lopez, A., Rollins, A. W., Roberts, J. M., Price, D., Peischl, J., Nault, B. A., Møller, K. H., Miller, D. O., Meinardi, S., Li, Q., Lamarque, J. F., Kupc, A., Kjaergaard, H. G., Kinnison, D., Jimenez, J. L., Jernigan, C. M., Hornbrook, R. S., Hills, A., Dollner, M., Day, D. A., Cuevas, C. A., Campuzano-Jost, P., Burkholder, J., Paul Bui, T., Brune, W. H., Brown, S. S., Brock, C. A., Bourgeois, I., Blake, D. R., Apel, E. C., and Ryerson, T. B.: Global airborne sampling reveals a previously unobserved dimethyl sulfide oxidation mechanism in the marine atmosphere, P. Natl. Acad. Sci. USA, 117, 45054510, https://doi.org/10.1073/pnas.1919344117, 2020.

Vollmer, B., Ostrenga, D., Savtchenko, A., Johnson, J., Wei, J., Teng, W., and Gerasimov, I.: Making Earth Science Data Records for Use in Research Environments (MEaSUREs) Projects Data and Services at the GES DISC, AGU Fall Meet. Abstr., San Francisco, CA, 5 December 2011, 1407, 2011.

Warren, D. R. and Seinfeld, J. H.: Prediction of aerosol concentrations resulting from a burst of nucleation, J. Colloid Interf. Sci., 105, 136-142, https://doi.org/10.1016/0021-9797(85)90356-x, 1985.

Warren, S. G., Hahn, C. H., London, J., Chervin, R. M., and Jenne, R. L.: Global Distribution of Total Cloud Cover and Cloud Type Amounts Over the Ocean (No. NCAR/TN317+STR), University Corporation for Atmospheric Research, https://doi.org/10.5065/D6QC01D1, 1988.

Wennberg, P. O., Bates, K. H., Crounse, J. D., Dodson, L. G., McVay, R. C., Mertens, L. A., Nguyen, T. B., Praske, E., Schwantes, R. H., Smarte, M. D., Clair, J. M. S., Teng, A. P., Zhang, X., and Seinfeld, J. H.: Gas-Phase Reactions of Isoprene and Its Major Oxidation Products, Chem. Rev., 118, 3337-3390, https://doi.org/10.1021/acs.chemrev.7b00439, 2018.

Werdell, P. J. and Bailey, S. W.: The SeaWiFS Bio-optical Archive and Storage System (SeaBASS): Current architecture and implementation, NASA Tech. Memo. 2002-211617, edited by: Fargion, G. S. and McClain, C. R., NASA Goddard Space Flight Center, Greenbelt, Maryland, 45 pp., https://doi.org/10.5067/SeaBASS/NAAMES/DATA001 (last access: 9 April 2020), 2002.

Whittlestone, S. and Zahorowski, W.: Baseline radon detectors for shipboard use: Development and deployment in the First Aerosol Characterization Experiment (ACE 1), J. Geophys. Res., 103, 16743-16751, https://doi.org/10.1029/98jd00687, 1998.
Williams, J., de Reus, M., Krejci, R., Fischer, H., and Ström, J.: Application of the variability-size relationship to atmospheric aerosol studies: estimating aerosol lifetimes and ages, Atmos. Chem. Phys., 2, 133-145, https://doi.org/10.5194/acp-2-1332002, 2002.

Yang, M., Bell, T. G., Hopkins, F. E., and Smyth, T. J.: Attribution of atmospheric sulfur dioxide over the English Channel to dimethyl sulfide and changing ship emissions, Atmos. Chem. Phys., 16, 4771-4783, https://doi.org/10.5194/acp-16-4771-2016, 2016.

Yoch, D. C.: Dimethylsulfoniopropionate: Its Sources, Role in the Marine Food Web, and Biological Degradation to Dimethylsulfide, Appl. Environ. Microb., 68, 5804-5815, https://doi.org/10.1128/AEM.68.12.5804-5815.2002, 2002.

Yoon, Y. J. and Brimblecombe, P.: Modelling the contribution of sea salt and dimethyl sulfide derived aerosol to marine CCN, Atmos. Chem. Phys., 2, 17-30, https://doi.org/10.5194/acp-2-172002, 2002.

Yu, F. and Luo, G.: Simulation of particle size distribution with a global aerosol model: contribution of nucleation to aerosol and CCN number concentrations, Atmos. Chem. Phys., 9, 76917710, https://doi.org/10.5194/acp-9-7691-2009, 2009.

Yue, G. K. and Deepak, A.: Temperature-dependence of the formation of sulfate aerosols in the stratosphere, J. Geophys. Res., 87 3128-3134, https://doi.org/10.1029/JC087iC04p03128, 1982.

Zavarsky, A., Booge, D., Fiehn, A., Krüger, K., Atlas, E., and Marandino, C.: The Influence of Air-Sea Fluxes on Atmospheric Aerosols During the Summer Monsoon Over the Tropical Indian Ocean, Geophys. Res. Lett., 45, 418-426, https://doi.org/10.1002/2017GL076410, 2018.

Zhang, B., Owen, R. C., Perlinger, J. A., Kumar, A., Wu, S., Val Martin, M., Kramer, L., Helmig, D., and Honrath, R. E.: A semi-Lagrangian view of ozone production tendency in North American outflow in the summers of 2009 and 2010, Atmos. Chem. Phys., 14, 2267-2287, https://doi.org/10.5194/acp-142267-2014, 2014.

Zorn, S. R., Drewnick, F., Schott, M., Hoffmann, T., and Borrmann, S.: Characterization of the South Atlantic marine boundary layer aerosol using an aerodyne aerosol mass spectrometer, Atmos. Chem. Phys., 8, 4711-4728, https://doi.org/10.5194/acp-8-47112008, 2008. 